Article

\title{
Fragmented Forest Patches in the Indian Himalayas Preserve Unique Components of Biodiversity: Investigation of the Floristic Composition and Phytoclimate of the Unexplored Bani Valley
}

\author{
Sumit Singh ${ }^{1,2,+\left(\mathbb{D}, \text { Bikarma Singh }^{1,3, *,+}+\mathbb{D} \text {, Opender Surmal }\right.}{ }^{1,2} \mathbb{D}$, Mudasir Nazir Bhat ${ }^{1,2}$, Bishander Singh $4 \mathbb{D}^{\mathbb{D}}$ \\ and Carmelo Maria Musarella ${ }^{5}$ (D)
}

check for

updates

Citation: Singh, S.; Singh, B.; Surmal, O.; Bhat, M.N.; Singh, B.; Musarella, C.M. Fragmented Forest Patches in the Indian Himalayas Preserve Unique Components of Biodiversity: Investigation of the Floristic

Composition and Phytoclimate of the Unexplored Bani Valley. Sustainability 2021, 13, 6063. https://doi.org/ $10.3390 /$ su13116063

Academic Editors:

Kevin Cianfaglione,

Angela Curtean-Bănăduc and

Doru Bănăduc

Received: 22 March 2021

Accepted: 20 May 2021

Published: 27 May 2021

Publisher's Note: MDPI stays neutral with regard to jurisdictional claims in published maps and institutional affiliations.

Copyright: (c) 2021 by the authors. Licensee MDPI, Basel, Switzerland. This article is an open access article distributed under the terms and conditions of the Creative Commons Attribution (CC BY) license (https:// creativecommons.org/licenses/by/ $4.0 /)$.
1 Academyof Scientific and Innovative Research (AcSIR), Ghaziabad 201002, Uttar Pradesh, India; ssumitthakur14@gmail.com (S.S.); rajputop225@gmail.com (O.S.); mudii644@gmail.com (M.N.B.)

2 Plant Sciences (Biodiversity and Applied Botany Division), CSIR-Indian Institute of Integrative Medicine, Canal Road, Jammu 180001, Jammu and Kashmir, India

3 Botanic Garden Division, CSIR-National Botanical Research Institute, Rana Pratap Marg, Lucknow 226001, Uttar Pradesh, India

4 Department of Botany, Veer Kunwar Singh University, Arrah 802301, Bihar, India; bishander85@gmail.com

5 Department of Agraria, Mediterranea University of Reggio Calabria, Feo di Vito snc, 89122 Reggio Calabria, Italy; carmelo.musarella@unirc.it

* Correspondence: drbikarma.singh@nbri.res.in

+ First authors.

Abstract: Subtropical and temperate forests are amongst the most threatened habitats of Asia, due to large-scale habitat loss and the fragmentation of landscapes. Inspite of these, the Asiatic regions preserve their endemic biodiversity, and provide a favorable environment for the abundant growth of vegetation. In the Himalayas, many interior regions are still unexplored from a biodiversity perspective, due to remote locations and high snow-clad mountains. In this study, we investigated the unexplored Bani Valley in order to reduce the gap of uninventorized areas of rich biodiversity in the Himalayas and formulate plant conservation and management strategies. Thirteen field expedition tours were undertaken during 2017 and 2020 for data collection in different growing seasons in the study area. All plant species were collected as voucher samples, identified, and deposited in the internationally recognized Janaki Ammal Herbarium (acronym RRLH). GPS points were recorded in order to study the forest types and vegetation components of the study area. A total of 196 plant species belonging to 166 genera and 68 families were identified in Bani Valley, covering a total area of $2651 \mathrm{~km}^{2}$. Approximately $70.62 \%$ of the species were native and $29.38 \%$ were non-native. In total, $46 \%$ of species were Indo-Malayan, followed by $22 \%$ Palearctic species. In angiosperms, dicotyledon species $(68.37 \%)$ dominated. Poales were the most dominant order, with 38 species (19.38\%). The most abundant families were Poaceae with 29 species (14.79\%), Fabaceae (17, 8.67\%), Rosaceae, Cyperaceae, and Asteraceae (9, 4.59\% each). The life form analysis showed $50 \%$ of species as phanerophytes, followed by therophytes $(25.77 \%)$. The leaf size spectra show mesophyllous species $(34.69 \%)$ as the dominant group. The IUCN Red List of Threatened Plants categorized Ailanthus altissima as endangered (EN), Aegle marmelos and Quercus oblongata as near threatened (NT), Ulmus wallichiana and Plantago lanceolata as vulnerable (VU), Taxus baccata and 75 other species as least concern (LC), and 2 species as data deficient (DD). The remaining 113 species of plants had not been evaluated according to the IUCN Red List of Threatened Species. This study will help to shape conservation and management plans for threatened species for future implementation, and will help in biodiversity conservation. This study will serve as a database for future reference materials in terms of biodiversity management.

Keywords: biodiversity conservation; biological spectrum; phenology; leaf spectra; IUCN; native plants; Himalayas 


\section{Introduction}

The origin of life on earth is a fascinating subject that can be studied through observations made today, and these observations, coupled with climate change over time, can provide answers as to how biodiversity has changed over time [1]. High-altitude mountainous belts safeguard important biodiversity and the scenic, aesthetic value of landscapes [2-5], provide ecosystem services to benefit human well-being, and are essential for a sustainable world [6-8]. Plant adaptation adjusts a life form to certain ecological conditions; thus, it has been widely used in the analysis of flora and vegetation [9]. The forms and structures of plant communities can be explored by classifying the species involved into categories reflecting their environmental relationships [10-13], and thus, plant communities can also be categorized in terms of leaf size and leaf form [14,15]. It has been shown that studying the biological spectrum is useful in comparing geographically separated plant communities, and is regarded as an indicator of changing environments [16]. Large-scale patterns of plant distribution are very well known, but regional- or local-scale study of plant assemblage is important for local action in biodiversity conservation [17]. Raunkiaer's classification, interlinked to climatic conditions and developed for the climate, is usually the temperate season, as the winter frost ends the plants' growing season [17-19]. Under this system, the life-forms were classified into five main groups, i.e., phanerophytes, chamaephytes, hemicryptophytes, cryptophytes, and therophytes [20]. This is supported by the observation that grassland vegetation in high-altitude regions is usually dominated by hemicryptophytes [21]. Raunkiaer's normal spectrum indicates a phanerophyte community, and the deviation determines the phytoclimatic nature of the vegetation composition of any particular given region [22]. Determining the difference between Raunkiaer's normal spectrum and the biological spectrum of life-forms allows us to discover the dominant lifeform that characterizes the phytoclimate of the study area in question [23]. Therefore, the life form study is an important factor in ecological studies and vegetation description, ranking next to floristic composition and biodiversity surveys $[24,25]$.

High mountain areas occupy $3 \%$ of the world's surface, wherein there are about 10,000 plant species, which represents approximately $4 \%$ of the total species diversity of the planet [26]. However, as one ascends a mountain, a reduction in the number species is observed, due to the harsh environmental conditions [27]. On the other hand, the mountainous regions (including the valleys and the lowlands that surround the reliefs) show a great species richness, despite the species poverty of their peaks. This can be explained by considering that the maximum slope of an area can be understood as a proxy of its environmental heterogeneity [28]. In addition, mountains have great conservation value, harboring numerous endemic, rare, and/or threatened taxa and ecosystems [29]. However, this natural heritage is threatened by changes in landuse and by climate change [21]. The climatic changes are related to changes in the distribution of species [30]. Thus, their altitudinal changes are reliably reflected in changes in temperature [31], responding more quickly to climate warming than other regions [32,33]. For this reason, research in mountainous areas-including the botanization of species, carefully registering the collection altitudes-is of great interest [34]. It is on the southern slopes of the Himalayas that the greatest unevenness is recorded globally. In addition, this was the pioneer mountain range in the series of tectonic movements that wiped out the Paleo-Tethys Ocean. This movement is still ongoing, and will culminate in the closure of the Strait of Gibraltar. A comparison of the general patterns obtained in the Himalayas (Bani Valley) and other places in this group of "circum-Tethys" ranges would enrich future research. At the other extreme, around the Strait of Gibraltar, are located the Betic ranges (Spain) and the Rif and Atlas Mountains (Morocco), whose endemic flora were studied by Pérez-García et al. [35]. Compared to the flora of the Himalayas (Bani Valley), it is observed that the Betic and Rif Mountains' flora have a lower weight than the Poaceae, in exchange for a large increase in Asteraceae, Caryophyllaceae, Fabaceae, and Lamiaceae. In addition, they show a greater presence of hemicryptophytes and chamaephytes, in exchange for a lower proportion of therophytes and phanerophytes. 
In India, there are four major biodiversity hotspots: the Himalayas, the Western Ghats, Indo-Burma, and Sundaland. Of the reported 18,532 species of angiosperms from the country (ENVIS, 2021), about 50\% of species are recorded in the Himalayas [36]. A lot of floristic and ecological research works have been carried out in geographic regions of Jammu and Kashmir (J\&K) at different times [37-39]; however, there are still lots of unexplored pockets in the Himalayas, which may be unexplored due to their extreme climate, unapproachable terrain, and the fear of cross-border terrorism issues [40-43]. Plant collection and the dissemination of data on the floristic composition and phytoclimatic variables can impart a lot of knowledge to mankind, and fill the gap of unexplored regions. The Kathua district of J\&K is recognized as "the Gateway to the Union Territory (UT)" and is bestowed with varied topography and mountainous climatic conditions [44]. It covers a total area of $2651 \mathrm{~km}^{2}$, whose altitude varies from 350 to $6000 \mathrm{~m}$ above mean sea level (AMSL). The region is surrounded by the Jammu district to the northwest, the Doda and Udhampur districts to the north, the state of Himachal Pradesh to the east, and the state of Punjab to the south. The terrain is very diverse, consisting of rich agricultural areas along the Punjab border, plains sweeping eastward to the foothills of the Himalayas, and the mountainous alpine region in the northeast [44]. The Indian Census of 2011 recorded the total population as 191,988 (available at https:/ / censusindia.gov.in, accessed on 10 February 2021). The climatic conditions vary depending on the geographical location and altitude; plains areas experience a subtropical climate, and the mountainous region to the north experiences a temperate climate. Bani Valley is a mountainous part of this district that lies towards the extreme north of India, is a part of the Northwestern Himalayan Region, and is categorized as a region of the Shivalik range. The region is under-explored from a floristic point of view, and there is no literature available to date on its plant diversity or phytoclimatic conditions. Therefore, our aim was to undertake a detailed floristic investigation of the Bani Valley. The Bani Valley presents a unique climate, bestowed with natural beauty, vegetation, and topography for studying the biodiversity (especially for medicinal plants) of the Northwestern Himalayan Region. The present study of the vegetation composition of the Bani Valley could be used as an example in India for other similar vegetation types, and for phytoclimatic study in particular.

\section{Materials and Methods}

\subsection{Study Area}

Bani Valley (Figure 1) is situated in the interior region of the Kathua district (J\&K). It lies between latitude $32^{\circ} 52^{\prime} 33.15^{\prime \prime} \mathrm{N}$ and longitude $75^{\circ} 48^{\prime} 14.53^{\prime \prime} \mathrm{E}$, and the elevation ranges from 1200 to $2001 \mathrm{~m}$ AMSL, covering a total area of $468 \mathrm{~km}^{2}$. The region is part of Western Himalaya, and the valley is situated at the bank of the SewaRiver, representing one of the northernmost parts of the Kathua district. This area is $85 \mathrm{~km}$ from the Basohli tehsil, and approximately $152 \mathrm{~km}$ from the town of Kathua and about $236 \mathrm{~km}$ from the UT capital, Jammu. The only way to reach the Bani Valley is by road.

The climate of the study region ranges from subtropical to temperate climates. The high mountainous hills of the Bani Valley are covered with snow and ice for 2-3 months per year. The different seasons prevailing in Bani Valley can be divided into four distinct intervals: summer, spring, rainy, and winter. The summer temperature varies from $18-45^{\circ} \mathrm{C}$, and the winter temperature from $0-15{ }^{\circ} \mathrm{C}$. The annual rainfall varies from $1200-1530 \mathrm{~mm}$. About $85 \%$ of rainfall is received in the monsoon season, i.e., from July to September. The sudden cloud burst and heavy rainfall can cause landslides, and these sometimes block the route to the Bani Valley. The heavy rainfall and landslides combined with stream waters cause havoc for the people. 


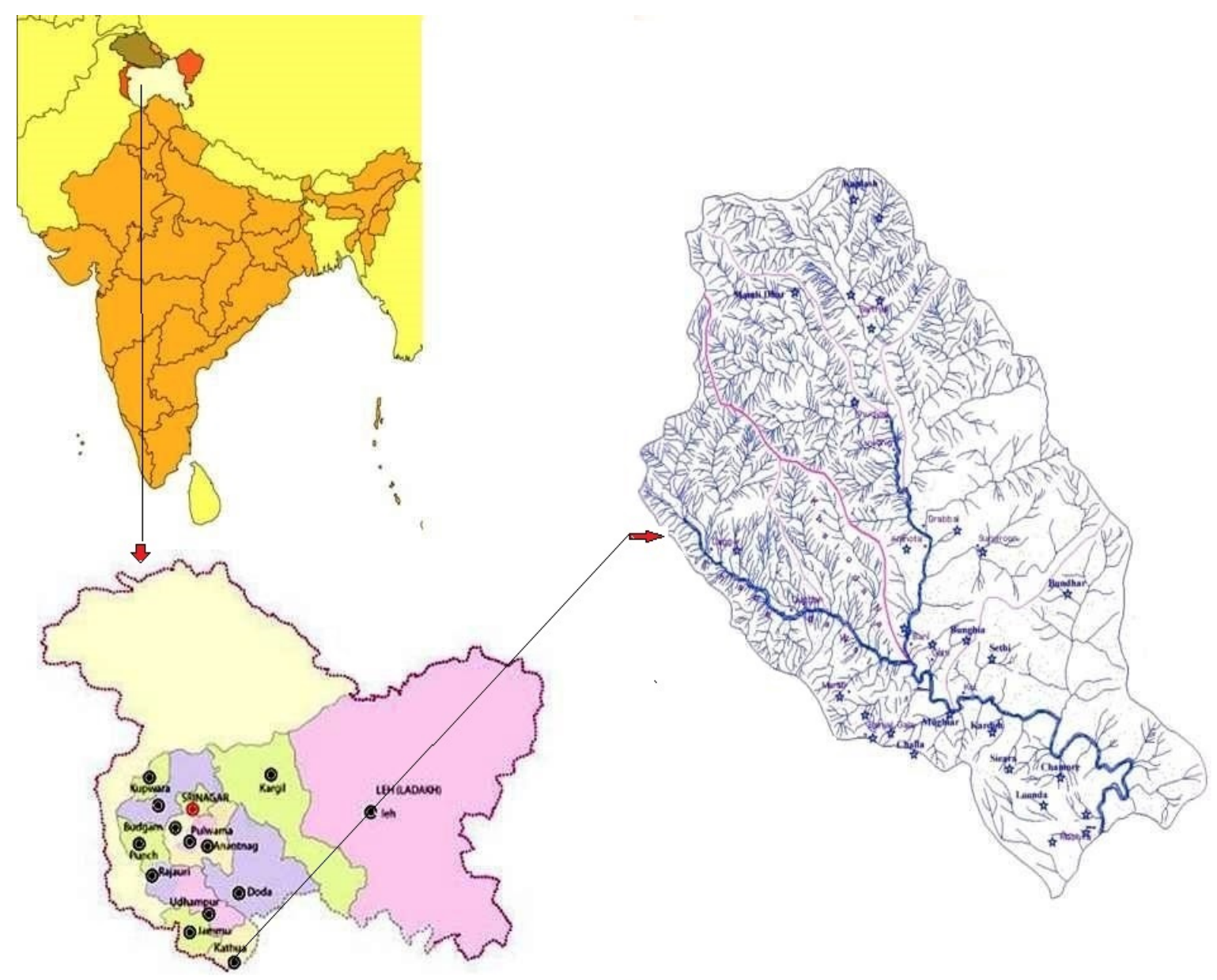

Figure 1. Location map of the Bani Valley (Jammu and Kashmir), Western Himalaya, India.

Using Champion and Seth's classification of forest types in India [45] as a reference, along with our own field observations, the forest types of Bani Valley can be divided into two categories, i.e., subtropical and temperate forests (Figure 2). The subtropical forests were sub-divided into two types-subtropical dry deciduous forests, and subtropical evergreen chir-pine forests. At lower altitudes, the trees were dominated by subtropical dry deciduous scrubs. The major dominant tree species of subtropical dry deciduous vegetation were Mallotus philipensis (Lam.) Müll.Arg., Terminalia bellirica (Gaertn.) Roxb., Ficus hispida L.f., Trema orientale (L.) Blume, Melia azedarach L., Toona sinensis (Juss.) M.Roem., Butea monosperma (Lam.) Kuntze, Syringa emodi Wall. ex Royle, and Lyonia ovalifolia (Wall.) Drude. The major shrub species of subtropical dry deciduous vegetation were Debregeasia saeneb (Forssk.) Hepper and J.R.I. Wood, Colebrookea oppositifolia Sm., Ototropis multiflora (DC.) H.Ohashi and K.Ohashi, Strobilanthes wallichii Nees, Cissampelos pariera Vell., and Rubus idaeus L. The dominant herbaceous species of subtropical dry deciduous vegetation were Trifolium pratense L., Lespedeza juncea (L.f.) Pers., Pilea scripta (Buch.-Ham. ex D.Don) Wedd., and Urtica dioica L. The above make up the vegetation in the foothills of the Himalayas.

The forests at elevations upto $1600 \mathrm{~m}$ are subtropical evergreen chirpine vegetation. Pinus roxburghii Sarg. is the most dominant tree species in chir-pine vegetation. The shrub species in evergreen chir-pine vegetation are Rubus ellipticus Sm., Cotinus coggygria Scop., and Desmodium elegans DC. The herb species found in evergreen chir-pine vegetation are Oreoseris gossypina (Royle) X.D.Xu and V.A.Funk, Barleria cristata L., Rungia pectinata (L.) Nees, Persicaria capitata (Buch.-Ham. ex D.Don) H.Gross, Achyranthes aspera L., and Euphorbia hirta L. The vegetation components above $1600 \mathrm{~m}$ are mostly temperate, and are dominated by Cedrus deodara (Roxb. ex D.Don) G.Don forests. Oak forests are also the dominant vegetation at these altitudes. The dominant tree species of these forests are 
C. deodara, Rhododendron arboreum Sm., Alnus nitida (Spach) Endl., Quercus oblongata D.Don, Acer caesium Wall. ex Brandis, and Celtis australis L. The dominant shrubby vegetation of temperate climates is characterized by Zanthoxylum armatum DC., Prinsepia utilis Royle, Rubus niveus Thunb., Isodon rugosus (Wall. ex Benth.) Codd, and Berberis lycium Royle. The herb species of temperate vegetation are Valeriana jatamansi Jones ex Roxb., Viola canescens Wall., Geranium wallichianum D.Don ex Sweet, Galium aparine L., and some fern species, such as Pteris vittata L., Pteris cretica L., Polystichum polyblepharum (Roem. ex Kunze) C.Presl, and Asplenium dalhousieae Hook.

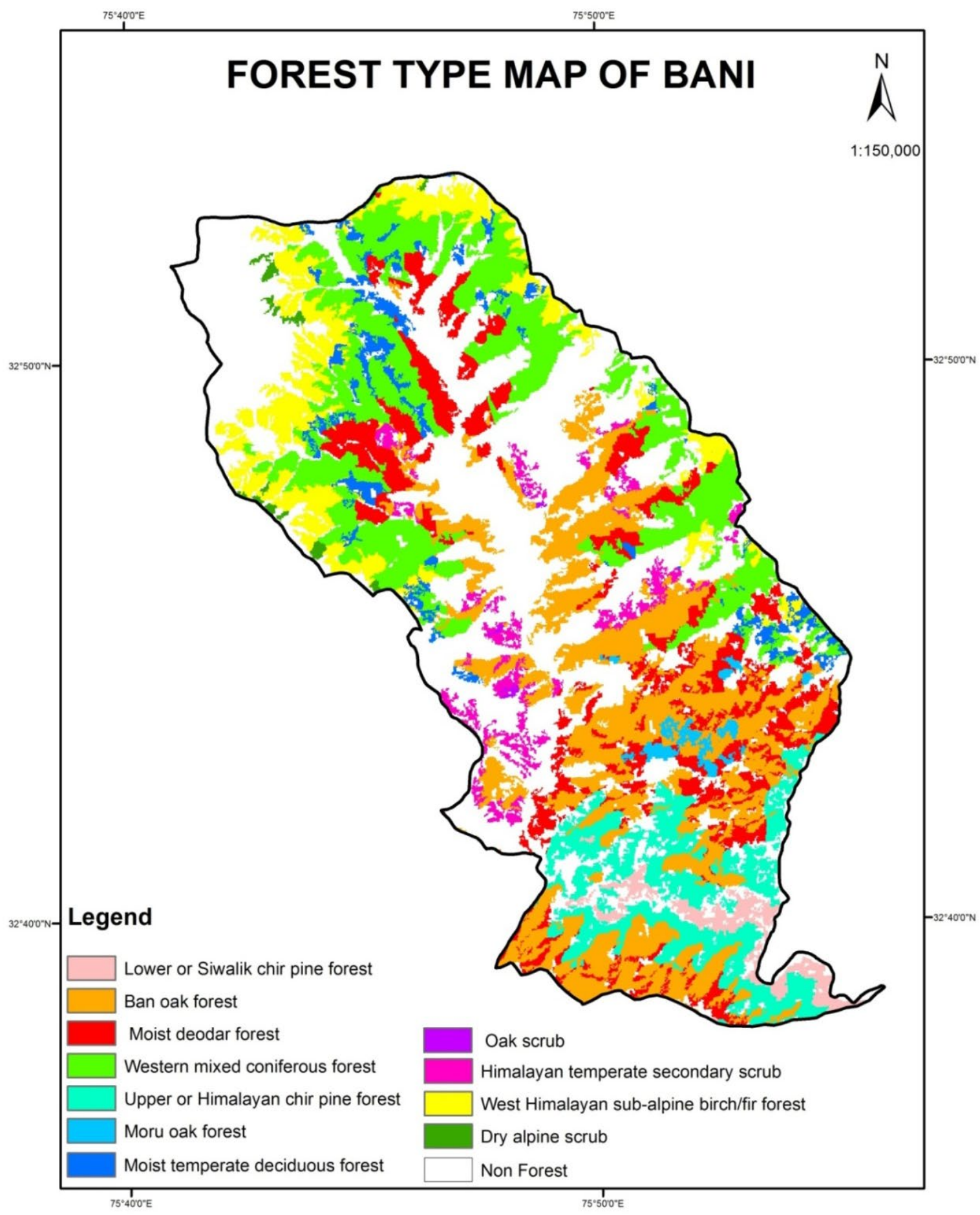

Figure 2. Forest types of the Bani Valley (Jammu and Kashmir), Western Himalaya, India. 
A total of 33 villages and 8096 households fall in the jurisdiction of Bani Valley, representing 45,996 people, of whom 23,889 are male and 22,107 are female; the recorded population density is $250 \mathrm{~km}^{-2}$ (https:/ / www.censusindia.co.in, accessed on 10 February 2021). The literacy rate is $44.27 \%$ (male: $57.16 \%$; female: $42.84 \%$ ). Bani tehsil is home to some Nomadic groups, such as Gujjars and Bakarwals. These are semi-pastoral ethnic communities of J\&K. They always move seasonally here and there as they have no permanent settlements. On the arrival of summer, these communities start their journey towards high altitude areas along with their livestock. With the onset of unfavorable conditions, they come down and settle in the plains areas of the Bani Valley.

\subsection{Data Collection}

\subsubsection{Field Surveys}

Thirteen field surveys and exploration tours were undertaken in the Bani Valley from March 2017 to July 2020 in different seasons, in order to study the botanical and ecological aspects of the vegetation composition. Floristic surveys were carried out in order to collect plant samples (angiosperms, gymnosperms, and lycophytes and ferns) from different altitudes of the study area. Lower plants (e.g., bryophytes, algae, fungi, lichens, and mosses) were excluded from this study. A total of 24 plots were laid out by first measuring randomly selected, $50 \mathrm{~m}$-long straight transects, with the help of a measuring tape, at different locations in the study area. Two altitude gradients (1201-1600 m a.m.s.l. for subtropical forest and 1601-2000 m a.m.s.l. for temperate forest) were selected. Flagtype points were marked and placed at $10 \mathrm{~m}$ intervals along the transect line, and also at distances of $10 \mathrm{~m}$ on both sides of the line, measured at right angles from the transect angle, thus marking off five $10 \mathrm{~m} \times 10 \mathrm{~m}$ quadrats on each side. Small transect lines were selected because the area had fragmented forest patches due to the occurrence of high hills and valleys, steep slopes, and deep gorges in the study area. Within each quadrat, all stems (trees, shrubs, and herbs) were counted and recorded. A total of 240 quadrats (120 on each side of the 50-m line) for trees $(10 \mathrm{~m} \times 10 \mathrm{~m})$, shrubs $(5 \mathrm{~m} \times 5 \mathrm{~m})$, and herbs $(1 \mathrm{~m} \times 1 \mathrm{~m})$ were used for the study. The diameters of the trees were measured using a diameter tape at $1 \mathrm{~m}$ height or above the buttress roots, and the trees' heights were recorded using clinometers. For multi-stem herbs (Poaceae), we divided the total stem number of the herbs by the mean number of stems per plant falling inside a $1 \mathrm{~m} \times 1 \mathrm{~m}$ quadrat, and rounded up the value for the purpose of analysis. Our focus was to collect the maximum number of plant samples bearing flowers and fruits in different seasons. A number of the quantitative measures typically employed in biodiversity plot studies were calculated for the two types of studied forest plots-subtropical and temperate forests. These included stem density, frequency, basal area, relative density, relative dominance, relative frequency, and importance value index (IVI) [46-51]. Data on plot heterogeneity (diversity and evenness of species) — such as the Dominance, Shannon, and Evenness indices-were computed using PAST software Version 3.21 and presented. The specimens collected from the field tours were dried and processed as per the standard operating procedure of Jain and Rao's modern herbarium techniques [52]. GPS coordinates, along with the digital photographs of all plant species available in the study, were taken. Plant samples were collected in triplicate and herbarium-prepared as per standard protocols, and the specimens of the collected plants were pasted on herbarium sheets $(42 \mathrm{~cm} \times 28 \mathrm{~cm} \pm 2 \mathrm{~cm})$. Each plant was given an accession number. Finally, the plant specimens were deposited in the Janaki Ammal Herbarium (acronym RRLH) of the CSIR-Indian Institute of Integrative Medicine Jammu (India). The herbarium acronyms are in accordance with Thiers [53].

\subsubsection{Presentation of Data}

The vegetation composition of the study area is identified based on morphological characteristics. The species, along with their habitat and habit, life-span, phenological period, Raunkiaer's life-form system classification, leaf spectra, and the distribution of the flowering periods of the study area, were provided. Families were arranged according to 
Angiosperm Phylogeny Group IV classifications [54]. Gymnosperms, and lycophytes and ferns, were placed after the flowering plants. The total number of orders, families, genera, and species under dicots and monocots identified from the study area was also prepared. IUCN Red List statuses were provided by consulting their website: www.iucnredlist.org.

\subsubsection{Literature Sources}

The identities of plants were confirmed from scientific studies published in journals, books, revisionary works, and monographs available in the libraries of CSIR-Indian Institute of Integrative Medicine (IIIM) and Jammu University. Plant species were botanically compared with the help of Flora of Udhampur [55], Flora of Jammu and Plants of Neighbourhood [56], Flora of Trikuta Hills [57], Handbook of Medicinal Herbs [58], and Illustration of Jammu Plants [59]. Angiosperm Phylogeny Group IV was used to classify the plant species, and the species list of the plants was checked using POWO (available at http: / / www.powo.org), the International Plant Names Index (available at http:/ / www.ipni.org), and Tropicos (available at https: / / www.tropicos.org).

For each plant species, we attributed a life-form following Raunkiaer's classification, and a leaf size, as categorical variables: (1) leptophyllous $\left(<25 \mathrm{~mm}^{2}\right)$; (2) nanophyllous (25-225 mm²); (3) microphyllous (225-2025 mm²); (4) mesophyllous (2025-4500 mm²); and (5) megaphyllous (4500-1225 $\mathrm{mm}^{2}$ ). A biological spectrum was prepared for the study area, which was subsequently compared with Raunkiaer's normal spectrum in order to determine the phytoclimate and vegetation composition of the study area.

For studying the phenological periods of different species, we categorized different months of the year as different seasons: summer (April-June); spring (January-March); rainy (July-September); and winter (October-December). Flowering periods were recorded from our field observations, and plant sample collection was performed over four continuous years of data collection from the study area.

\section{Results and Discussion}

\subsection{Diversity of Taxa and Families}

In the present study, a total of 547 sampled vouchers were collected, representing 196 species of 166 genera distributed in 68 families under 27 orders (Table 1). Sixty-eight percent of the species were dicotyledons, followed by monocotyledons $(23.97 \%)$, lycophytes and ferns $(5.10 \%)$, and gymnosperms $(2.55 \%)$. The dominant orders of the angiosperms were Poales with 38 taxa (19.38\%), Rosales (25, 12.75\%), Fabales (16, 8.16\%), Sapindales (15, $7.65 \%)$, Lamiales $(13,6.63 \%)$, Asterales (9, 4.59\%), Caryophyllales (8, 4.04\%), Malpighiales (7, $3.57 \%)$, Ranunculales $(6,3.06 \%)$, and Cucurbitales $(5,2.55 \%)$ (Table 1$)$. All of the angiosperm species are arranged according to the APG IV system of classification [54], followed by gymnosperms, and lycophytes and ferns.

Table 1. Total diversity of plant taxa in the Bani Valley (Jammu and Kashmir), Western Himalaya, India.

\begin{tabular}{cccccccc}
\hline Group & Orders & Families & Genera & \multicolumn{4}{c}{ Taxa } \\
\hline & & & & Herbs & Shrubs & Trees & Total \\
\hline Dicots & 20 & 52 & 117 & 48 & 34 & 52 & 134 \\
Monocots & 5 & 10 & 37 & 46 & 1 & 0 & 47 \\
Lycophytes and ferns & 1 & 4 & 8 & 10 & 0 & 0 & 10 \\
Gymnosperms & 1 & 2 & 4 & 0 & 0 & 5 & 5 \\
Total & 27 & 68 & 166 & 104 & 35 & 57 & 196 \\
\hline
\end{tabular}

The top 10 dominant families reported in the study area in terms of species richness were Poaceae $(29,14.79 \%)$, followed by Fabaceae $(17,8.67 \%)$, Rosaceae, Cyperaceae, and Asteraceae (9, 4.59\% each). A total of 11 families comprising 2 species $(1.02 \%), 4$ families comprising 3 species (1.53\%), and 4 families comprising 4 species (2.04\%) were also reported. Another 37 monotypic families comprising single species were also identified in the study area. In terms of the highest number of genera, the 10 most dominant plant families were 
Poaceae (23, 13.93\%), Fabaceae (17, 10.30\%), Asteraceae (9, 5.45\%), Acanthaceae (6, 3.63\%), Cyperaceae, Lamiaceae, Rosaceae and Urticaceae (5, 3.03\% each), Pteridaceae (4, 2.42\%), and Polygonaceae $(2,1.21 \%)$.

Floristic studies carried out by Dhar and Kachroo [60] in the Kashmir Himalayas have shown a somewhat similar pattern of diversity of plant taxa. According to their work, Asteraceae, Lamiaceae, Poaceae, Rosaceae, and Polygonaceae were dominant plant families, similar to our own research findings. Similarly, Sharma et al. [61] carried out similar studies in the Sangla Valley of the Northwestern Himalayan Region, and reported Asteraceae, Rosaceae, Apiaceae, and Ranunculaceae as the dominant families. Our findings were also supported by the dominance of Poaceae and Asteraceae reported in the flora of the LahaulSpiti and Bhaba Valleys of Western Himalaya and Himachal Pradesh [62,63]. Species richness was similar at the same altitude and climatic conditions. Zent and Zent [64] studied the floristic composition, structure, and diversity of forest plots in the Sierra Maigualida, Venezuelan Guayana, and reported 533 species, of which Fabaceae represents the most dominant family. There are other, similar studies that support our findings, including the studies carried out by Agrawal [65], Shaheen et al. [66], and Haq et al. [67].

The genus Cyperus L. comprises five species, and was the most dominant monocot, whereas the genera comprising three species were Ficus Tourn. ex L., Persicaria Mill., Rubus L., and Setaria P.Beauv. The 19 well-represented genera containing 2 species were Asplenium L., Carex L., Chrysopogon Trin., Clematis L., Commelina Plum. ex L., Cymbopogon Spreng., Euphorbia L., Galium L., Isodon (Schard. ex Benth.) Spach, Pilea Lindl., Pinus L., Prunus L., Pteris L., Pyrus L., Rumex L., Saccharum L., Solanum L., Thalictrum Tourn. ex L., and Terminalia L. The remaining 139 taxa, belonging to monotypic genera, were also recorded. In a similar environment, a study on floristic diversity and the distribution patterns of plant communities along altitudinal gradients was carried out by Sharma et al. [61] in the Sangla Valley of the Northwestern Himalayan Region, and reported Artemisia L., Polygonum Juss., Saussurea DC., Berberis L., Thalictrum Tourn. ex L., Geranium Tourn. ex L., Juniperus L., Nepeta L., Potentilla L., Poa L., Rosa L., and Salix L. as the dominant genera. There are other similar studies which support our findings, including the studies carried out by Chawla et al. [62], Chowdhery and Wadhwa [63], Agrawal [65], Shaheen et al. [66], Dhaliwal and Sharma [68], and Haq et al. [69].

\subsection{Species Diversity in Different Growth Form}

The present floristic and vegetative composition analysis of the study area shows a total of 134 dicots (68.37\%), 47 monocots (24.23\%), 10 lycophytes and ferns (5.15\%), and 5 gymnosperms (2.57\%). Among these, 104 of the identified taxa were herbs (53.06\%), followed by shrubs (17.85\%) and trees (29.08\%). Amongst the total dicot taxa, herbs, shrubs, and tree habits were represented by 48, 34, and 52 taxa, respectively, whereas the total monocot group of plants, herbs and shrubs, comprised of 46 and 1 species, respectively. No tree species of monocots were recorded in the study area. The epiphytes recorded were not included while studying the quadrat data for analysis of different diversity indices.

The results of 240 quadrats indicated that the subtropical forests of the Bani Valley were characterized by 415 trees, 480 shrubs, and 96,000 herbs, representing 45, 23, and 42 species of trees, shrubs, and herbs, respectively. The temperate forest plots indicated 400 trees (19 species), 355 shrubs (20 species), and 162,800 herbs (59 species) (Table 2). The Dominance, Shannon, and Evenness indices analyzed for these two types of forests (subtropical and temperate forests) of the Bani Valley are also presented in Table 2. 
Table 2. Qualitative analysis of plant diversity of the Bani Valley (Jammu and Kashmir), Western Himalaya, India.

\begin{tabular}{|c|c|c|c|c|c|c|}
\hline Habit & & $\begin{array}{l}\text { Number } \\
\text { of Taxa }\end{array}$ & $\begin{array}{l}\text { Number of } \\
\text { Individuals }\end{array}$ & $\begin{array}{l}\text { Dominance } \\
\text { Index }\end{array}$ & $\begin{array}{l}\text { Shannon } \\
\text { Index }\end{array}$ & $\begin{array}{c}\text { Evenness } \\
\text { Index }\end{array}$ \\
\hline A. Subtropical & Trees & 45 & 415 & 0.41 & 3.51 & 0.74 \\
\hline forests & Shrubs & 23 & 480 & 0.08 & 2.75 & 0.68 \\
\hline$(1201-1600 \mathrm{~m})$ & Herbs & 42 & 96,000 & 0.06 & 3.01 & 0.76 \\
\hline B. Temperate & Trees & 19 & 400 & 0.11 & 2.53 & 0.66 \\
\hline forests & Shrubs & 20 & 355 & 0.12 & 2.31 & 0.76 \\
\hline$(1601-2000 \mathrm{~m})$ & Herbs & 59 & 162,800 & 0.03 & 3.77 & 0.77 \\
\hline
\end{tabular}

At low altitudes in the subtropical forests of the study area in the Bani Valley, angiosperm taxa were dominant. The gymnosperms were mostly confined to high-altitude regions of the study area. Monocots, especially Poaceae, were mostly confined to the higher elevations. Trees and shrubs were mostly confined to lower elevations. The earlier research carried out on the species diversity in Western Himalaya shows a somewhat similar pattern. Comparing these research findings with earlier works, such as that of Mir et al. [70] in the Kashmir Himalayas, shows similarity in findings mostly regarding the dominant coniferous forests. Similarly, Dogra et al. [71] studied plant diversity in the western Himalayas of Himachal Pradesh in similar climatic conditions and elevations, and our research shows similarities in terms of family composition and dominant species. Gaston et al. [72] also carried out similar studies in the western Himalayas, which showed a similar type of species diversity in similar types of vegetation. Other researchers, such as Gairola et al. [73], have performed floristic analysis in the western Himalayas of the Garhwal division of Uttarakhand, and the species richness and different growth forms were similar to the present findings.

\subsection{Life Span}

In the study area, 50 taxa of annual plants, representing $25.51 \%$, were therophytes. Some of the common annual plants growing in the study area were Juncus bufonius L., Poa annua L., Solanum virginianum L., Cyperus rotundus L., Euphorbia thymifolia L., etc. A total of 146 were perennial plants, comprising $74.49 \%$ of the total flora of the study area, which could survive in the most unusual and unfavorable conditions. These perennial plants were mostly trees and shrubs, which were more dominant at low altitudes in warm, moist, subtropical forests. Some of the common perennial plants growing in the study area were Commelina benghalensis L., Rubus paniculatus Sm., Clematis graveolens Lindl., Carex brunnea Thunb., A. nitida, C. deodara, etc. At higher altitudes most of the plant life forms were therophytes, hemicryptophytes, and chamaephytes, and this could be the result of climatic factors and dry conditions favoring the growth of such species. Similar conditions are not inclusive for other groups, such as megaphanerophytes and nanophanerophytes.

The data on life-span findings from the Bani Valley were observed to be similar to those of Subramani et al. [74], who have carried out life-span studies in the Northwestern Himalayan Region. Another botanist, Saha [75] came across similar dominant life-forms in the Darjeeling regions of the northeastern Himalayas. In J\&K, Rawat and Adhikari [76] studied the Changthang plateau of the Ladakh region based on altitudinal gradients, and recorded similar observations. Other studies, such as those of Namgyal et al. [77], Klimes [78], and Pharswan et al. [79], also attained similar research findings in Western Himalaya. Nautiyal et al. [80] conducted similar studies at similar altitudes and climatic conditions in the Tungnath area of the Kumaon Himalayas.

\subsection{Life Form and Biological Spectrum}

The biological spectrum of the Bani Valley shows that phanerophytes, with 96 taxa $(48.97 \%)$, were the dominant group, followed by therophytes $(50,25.51 \%)$, hemicryptophytes $(30,15.31 \%)$, chamaephytes $(16,8.16 \%)$, and geophytes $(4,2.04 \%)$ (Figure 3 ). Among phanerophytes, megaphanerophytes $(61,31.12 \%)$ were more dominant than nano- 
phanerophytes $(35,17.86 \%)$. This research reveals that phanerophytes, chamaephytes, and therophytes constituted higher percentages of $48.97,8.16$, and $25.51 \%$, respectively, than in Raunkiear's normal spectra, exhibiting a "phanero-phamae- therophytic phytoclimate" (Figure 4). Furthermore, the plant life forms, i.e., hemicryptophytes (15.31\%) and geophytes $(2.04 \%)$, were comparatively smaller in percentage than in Raunkiaer's normal spectra (Table 3). The dominant three groups (phanerophytes, therophytes, and hemicryptophytes) constituted $89.79 \%$ of the total plant's life.

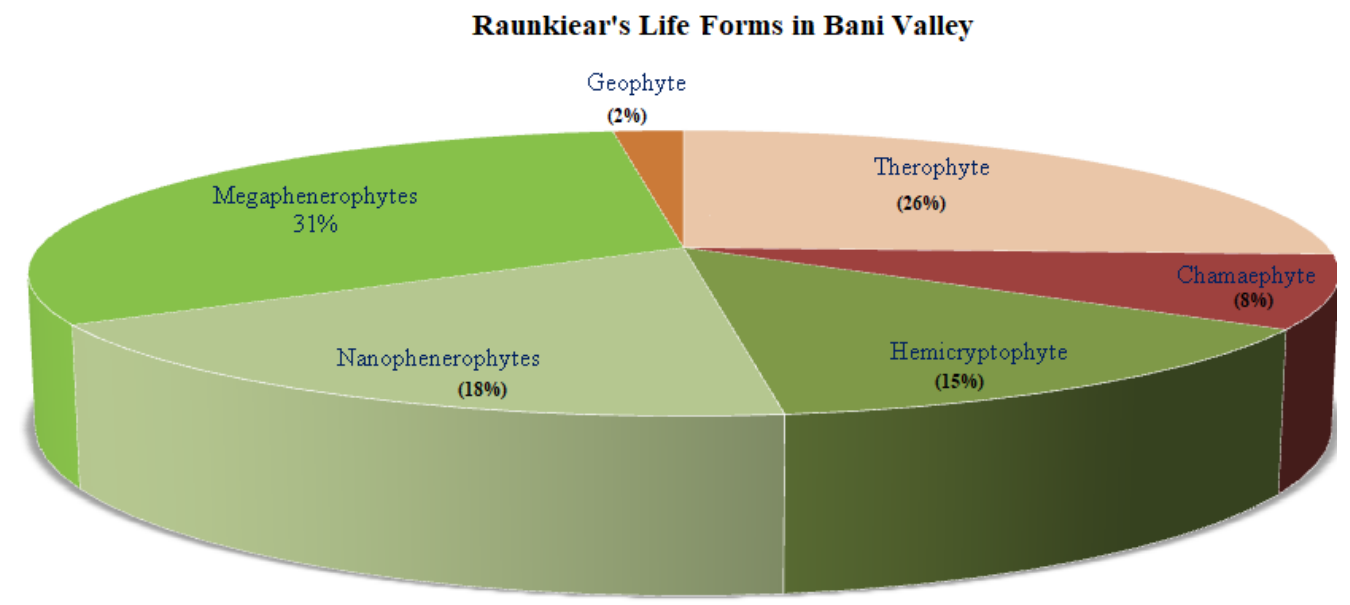

Figure 3. Biological spectra of the taxa recorded in the Bani Valley (Jammu and Kashmir), Western Himalaya, India, based on Raunkiaer's system of classification.

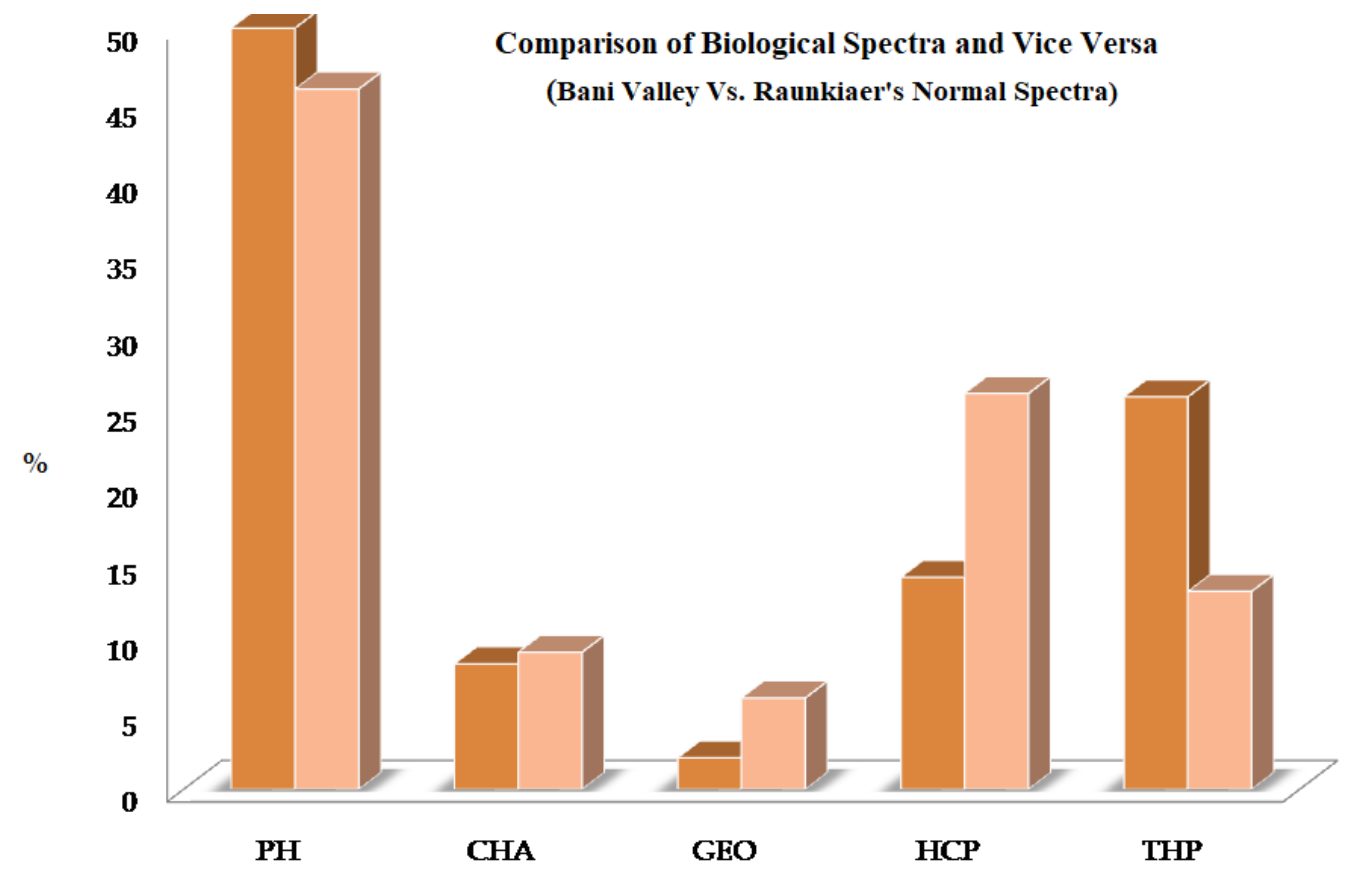

Figure 4. Comparison of the biological spectra of the taxa recorded in the Bani Valley (Jammu and Kashmir), Western Himalaya, India, with Raunkiaer's Normal Spectra (PH: Phanerophytes; CHA: Chamaephytes; GEO: Geophytes; HCP: Hemicryptophytes; THP: Therophytes). 
Table 3. Biological spectra (\% of all life forms) of the study area and its comparison with Raunkiaer's normal spectra.

\begin{tabular}{ccccc}
\hline $\begin{array}{c}\text { Raunkiaer's } \\
\text { Life Forms }\end{array}$ & $\begin{array}{c}\text { Total No. of } \\
\text { Species }\end{array}$ & $\begin{array}{c}\text { Biological Spectra (\%) } \\
\text { of the Bani Valley }\end{array}$ & $\begin{array}{c}\text { Raunkiaer'sNormal } \\
\text { Spectra (\%) }\end{array}$ & $\begin{array}{c}\text { Deviation = (Raunkiaer's Normal } \\
\text { Spectra-Biological Spectra) }\end{array}$ \\
\hline PH & 96 & 48.98 & 46.00 & 2.98 \\
CHA & 16 & 8.16 & 9.00 & -0.84 \\
GEO & 4 & 2.04 & 6.00 & -3.96 \\
HCP & 30 & 15.31 & 26.00 & -10.69 \\
THP & 50 & 25.51 & 13.00 & 12.51 \\
Total & 196 & 100.00 & 100.00 & 0.00 \\
\hline
\end{tabular}

(Note:PH: Phanerophytes; CHA: Chamaephytes; GEO: Geophytes; HCP: Hemicryptophytes; THP: Therophytes).

Therophytes growing in the Bani Valley showed the maximum divergence from Raunkiaer's normal spectra. The dominance of phanerophytes indicates that the study area was under mild biotic pressure. Many plant species were decreasing in the area at an alarming rate $[81,82]$. Therefore, we feel that it is the responsibility of the local people and forest departments to protect the plant species and unique vegetation composition of the Bani Valley.

Studies reveal that megaphanerophytes and nanophanerophytes were dominant in warmer, moist subtropical forests, whereas therophytes and hemicryptophytes are mostly present in the high-altitude regions of the Bani Valley. Similar studies were also carried out in Western Himalaya earlier by many botanists. Saxena et al. [83] performed studies on life forms at high altitudes in the Kumaon Himalayas. The results of our study were similar to their research findings. Other botanists, such as Singh and Bedi [84], and Das et al. [85], have also carried out similar research in different pockets of Western Himalaya, and when comparing the present research with earlier research findings, we find similar results.

\subsection{Leaf Size Spectrum}

The overall leaf size spectra of the Bani Valley were: 10 leptophyllous (5.10\%), 63 nanophyllous (32.14\%), 41 microphyllous (20.92\%), 68 mesophyllous $(34.69 \%)$, and 14 megaphyllous (7.14\%). Among the leaf size spectra, mesophyllous was found to be highest among plant species, followed by nanophyllous, microphyllous, megaphyllous, and leptophyllous. The results analysis of the leaf spectra of the Bani Valley concerning the Raunkiaer's life forms system is shown in Table 4 . We observed that the taxa with large leaves occur in warmer, moist climatic conditions, while the plants with smaller leaves are characteristic of cold and dry climatic conditions. Wright et al. [86] studied leaf data for 7670 plant species, along with climate data from 682 sites across the world, and concluded that large-leaved species predominate in wet, hot, and sunny environments, whereas small-leaved plant species were found in high-altitude areas [63]. In the present study, the plant species with microphyllous and nanophyllous leaves were confined to higher altitude regions, and this findingis consistent with the work carried out by Haq et al. [67]. The plant species with mesophyllous and megaphyllous leaves represent the characteristic vegetation in the low-altitude regions. A study carried out in the Keran Valley of the Kashmir Himalayas generated similar results [67]. The herbaceous flora were dominant at the upper reaches in both studies. This is because of similar altitudes and climatic conditions. Similarly, studies carried out by Shaheen et al. [87] in the Western Himalayan alpine regions of Kashmir show similar patterns of life forms. 
Table 4. Analysis by leaf size of life forms in the study area.

\begin{tabular}{ccccccc}
\hline Raunkiaer's Life Forms & Leptophyllous & Megaphyllous & Mesophyllous & Microphyllous & Nanophyllous & Total \\
\hline CHA & 0 & 0 & 6 & 3 & 7 & 16 \\
GEO & 0 & 1 & 2 & 0 & 7 & 12 \\
HCP & 1 & 0 & 10 & 20 & 30 \\
PH & 5 & 12 & 13 & 11 & 22 & 21 \\
THP & 4 & 1 & 68 & 41 & 50 \\
\hline Total & 10 & 14 & 196 \\
\hline
\end{tabular}

(Note: PH: Phanerophytes; CHA: Chamaephytes' GEO: Geophytes; HCP: Hemicryptophytes; THP: Therophytes).

\subsection{Phenological Periods}

The taxa showed flowering and fruiting in different seasons. The phenological periods of the plants of the Bani Valley were divided into four different groups of the year. From January to March, 17 taxa were recorded as being in the flowering stage $(8.67 \%)$, followed by 106 taxa flowering in April-June (54.08\%), 63 taxa from July to September $(32.14 \%)$, and $10(5.10 \%)$ from October to December (Figure 5). Most taxa from the study area were found to be in the flowering stage from April to June. The majority of the taxa bloomed from May to June. The Bani Valley falls under the temperate zone of the Northwestern Himalayan Region, and experiences vivid snowfall in most parts of the region. The perennating buds of the plants growing in such a climate remain dormant in order to overcome these adverse climatic conditions. This is the reason that leads to plants blooming in the spring and summer seasons. Even from July to September, many plant species were found to be in the flowering stage, and during this period the region experiences maximum rainfall. High rainfall allows the plants to grow and bloom. The findings of the present study correlate with similar studies undertaken by earlier researchers [88-93], which reached similar research findings.

October to December

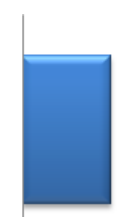

July to Septemeber

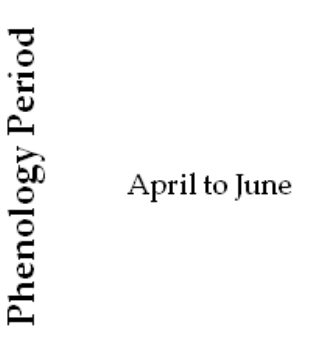

January to March
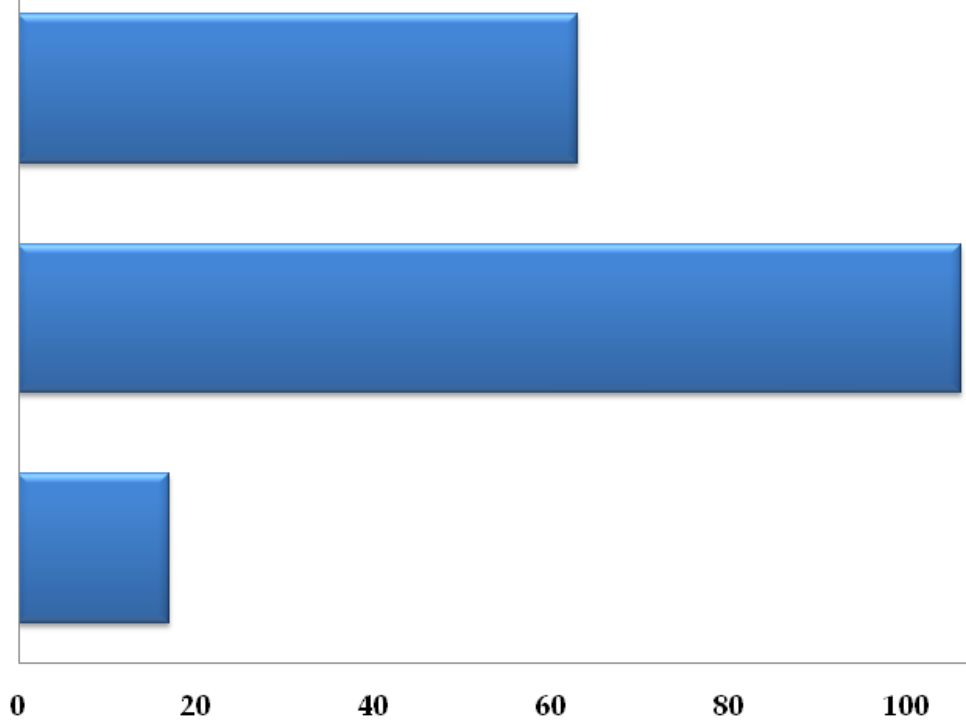

20

40

60

80

100

Number of Taxa

Figure 5. Analysis of the total number of taxa in different phenological periods of the year. 


\subsection{Invasive Species}

Out of a total of 196 species inventorized from the Bani Valley, 30\% (59 species) are alien/invasive species, while $70 \%$ are native to the Asian or Himalayan regions. These invasive species also show affinities of European, Eurasian, African, and American origin. Most of these alien species are cultivated or introduced as garden plants by the local people in the study area. The most common invasive plant species found to be growing in the region include species such as Ageratum conyzoides L., Argemone mexicana L., Arthraxon lancifolius (Trin.) Hochst., C. brunnea, Cynodon dactylon (L.) Pers., Euphorbia thymifolia L., Galinsoga parviflora Cav., J. bufonius, Malvastrum coromandelianum (L.) Garcke, Panicum virgatum L., Parthenium hysterophorus L., Prunus domestica L., R. idaeus, Setaria flavida (Retz.) Veldkamp, Setaria italica (L.) P.Beauv., and Solanum americanum Mill. (Table 5). These invasive plants also are reported as potential invaders in other parts of the Himalayas [69]. Alien plant species tend to have more phenotypic plasticity than native plants, and are usually superior to native plants in numerous fitness components; for this reason, they can colonize disturbed areas and natural habitats more resourcefully than native species [94-96]. Asteraceae, Poaceae, Brassicaceae, Fabaceae, and Lamiaceae are the families with the most invasive plant species found in India [97], and these families of invasive species are consistent with the findings of Wu et al. [98] for China, Lambdon et al. [99] for Europe, Khuroo et al. [100] for India, Randall [101] for Australia, and Diez et al. [102] for New Zealand. Out of all of the species recorded inthe Bani Valley, $30.41 \%$ are alien, most of which thrive in anthropogenically disturbed habitats. These values are comparable with those reported by Kohli et al. [103] from the Himachal Pradesh region of the Indian Himalayas. Khuroo et al. [104] reported that 8.5\% of Indian flora (1599 species belonging to 842 genera and 161 families) were alien plant species, most of which belonged to the Asteraceae (134 spp.), Papilionaceae (114 spp.) and Poaceae (106 spp.) families. Another study carried out by Haq et al. [69] reported Anthemis cotula L., Convolvulus arvensis L., Carduus onopordioides Fisch. ex M.Bieb., Datura stramonium L., Erigeron canadensis L., and Sisymbrium loeselii L. as the most invasive plant species growing in the Jammu and Kashmir Himalayas, and reported that climate change and biological invasions in the form of alien species are major drivers affecting biodiversity and ecosystem services.

\subsection{Conservation Status and IUCN Categories}

Among these 196 taxa of plants (Table 5), 113 had not been evaluated according to the IUCN Red List of Threatened Species [105]. There were 76 plant taxa mentioned under least concern (LC), 1 as endangered (EN), 2 as near-threatened (NT), 2 as vulnerable (VU), and 2 as data deficient (DD). Ailanthus altissima (Mill.) Swingle was the endangered species identified from the study area, whereas Ulmus wallichiana Planch. and Plantago lanceolata L. were the vulnerable species. Aegle marmelos (L.) Corrêa and Q. oblongata-categorized as NT-were also found to be growing in the Bani Valley. Taxus baccata L. and 75 other species are LC species recorded in the study area. Earlier works, such as that of Bijlwan et al. [106], studied the natural regeneration status of endangered plants i.e., T. baccata in the Northwestern Himalayan Region. Similarly, Lanker et al. [107] and Paul et al. [108] studied the genus Taxus L. in the northeast Himalayas, where this species was mentioned as a highly threatened plant due to anthropogenic factors and its use in medicine. The phytosociological analysis with ecological information reveals a study area that is floristically rich and, at the same time, under pressure from human activity. This research highlights the status and ecological distribution of the species in the study area, the ecological characteristics necessary for their survival, and the threats faced by some of the taxa designated by following the criteria devised by the IUCN. Various factors caused the depletion of the native flora from the study area. Anthropogenic activities were the major cause. Deforestation and overgrazing by livestock were other factors leading to the destruction of plant species. 
Table 5. List of plant taxa in the Bani Valley of Kathua district, Jammu and Kashmir, Western Himalaya, India.

\begin{tabular}{|c|c|c|c|c|c|c|c|c|c|c|c|c|}
\hline Plant Groups (APG IV) & $\begin{array}{l}\text { Voucher } \\
\text { Number }\end{array}$ & Habit & $\begin{array}{l}\text { Life } \\
\text { Span }\end{array}$ & $\begin{array}{l}\text { Phenology } \\
\text { Period }\end{array}$ & Habitat & $\begin{array}{l}\text { Raunkiaer's } \\
\text { Life Forms }\end{array}$ & $\begin{array}{c}\text { Sub-type of } \\
\text { Raunkiaer's } \\
\text { Life Forms }\end{array}$ & $\begin{array}{c}\text { Leaf } \\
\text { Spectrum }\end{array}$ & Leaf Shape & $\begin{array}{l}\text { Conservation } \\
\text { Status } \\
\text { (IUCN) }\end{array}$ & $\begin{array}{c}\text { Specific } \\
\text { Distribution }\end{array}$ & $\begin{array}{c}\text { Native (N)/ } \\
\text { Exotic (E) }\end{array}$ \\
\hline $\begin{array}{c}\text { I. MONOCOTS } \\
\text { Acorales Martinov } \\
\text { Acoraceae Martinov } \\
\text { Acorus calamus L. } \\
\text { Alismatales R.Br. ex Bercht. } \\
\text { \& J. Presl } \\
\text { Potamogetonaceae Bercht. } \\
\text { \& J.Presl }\end{array}$ & RRLH54665 & $\mathrm{H}$ & $\mathrm{P}$ & May-June & Streamside & GEO & & MES & Ensiform & LC & Native to Asia & $\mathrm{N}$ \\
\hline Potamogeton nodosus Poir. & RRLH55286 & $\mathrm{H}$ & $\mathrm{P}$ & Jul-Aug & Aquatic & $\mathrm{CHA}$ & & NP & Lanceolate & LC & $\begin{array}{l}\text { Native to North } \\
\text { America }\end{array}$ & $\mathrm{E}$ \\
\hline $\begin{array}{c}\text { Araceae Juss. } \\
\text { Arisaema flavum (Forssk.) } \\
\text { Schott } \\
\text { Juncaceae Juss. }\end{array}$ & RRLH55268 & $\mathrm{H}$ & $\mathrm{P}$ & July-Aug & Forest slopes & GEO & & MES & $\begin{array}{l}\text { Oblong to } \\
\text { lanceolate }\end{array}$ & NA & Native to Asia & $\mathrm{N}$ \\
\hline Juncus bufonius L. & RRLH55278 & $\mathrm{H}$ & A & May-Jun & Streamside & THP & & MES & Elliptic & LC & $\begin{array}{l}\text { Native to North } \\
\text { America }\end{array}$ & $\mathrm{E}$ \\
\hline $\begin{array}{l}\text { Smilacaceae Vent. } \\
\text { Smilax vaginata Decne. } \\
\text { Asparagales } \\
\text { Asparagaceae Juss. }\end{array}$ & RRLH54673 & $S$ & $\mathrm{P}$ & May-Aug & $\begin{array}{l}\text { Forest } \\
\text { thickets }\end{array}$ & $\mathrm{PH}$ & $\mathrm{NPH}$ & LEP & Ovate & NA & $\begin{array}{l}\text { Native to Asia and } \\
\text { Afghanistan }\end{array}$ & $\mathrm{N}$ \\
\hline Asparagus adscendens Roxb. & RRLH55270 & $\mathrm{H}$ & $\mathrm{P}$ & Nov-Dec & $\begin{array}{l}\text { Forest } \\
\text { thickets }\end{array}$ & $\mathrm{PH}$ & $\mathrm{NPH}$ & MIC & Spiny & NA & Native to India & $\mathrm{N}$ \\
\hline $\begin{array}{c}\text { Orchidaceae Juss. } \\
\text { Rhynchostylis retusa (L.) Blume } \\
\text { Commelinales Mirb. ex } \\
\text { Bercht. \& J. Presl } \\
\text { Commelinaceae Mirb. }\end{array}$ & RRLH55205 & $\mathrm{H}$ & A & May-Jun & Epiphytic & THP & & LEP & Lorate & NA & Native to Asia & $\mathrm{N}$ \\
\hline $\begin{array}{c}\text { Commelina benghalensis L. } \\
\text { Commelina communis L. } \\
\text { Poales Small } \\
\text { Cyperaceae Juss. }\end{array}$ & $\begin{array}{l}\text { RRLH54667 } \\
\text { RRLH54941 }\end{array}$ & $\begin{array}{l}\mathrm{H} \\
\mathrm{H}\end{array}$ & $\begin{array}{l}\mathrm{P} \\
\mathrm{A}\end{array}$ & $\begin{array}{l}\text { Apr-May } \\
\text { Apr-May }\end{array}$ & $\begin{array}{l}\text { Wet places } \\
\text { Moist places }\end{array}$ & $\begin{array}{l}\text { CHA } \\
\text { THP }\end{array}$ & & $\begin{array}{l}\text { MES } \\
\text { MES }\end{array}$ & $\begin{array}{c}\text { Ovate } \\
\text { Lanceolate }\end{array}$ & $\begin{array}{l}\text { LC } \\
\text { NA }\end{array}$ & $\begin{array}{l}\text { Native to Asia } \\
\text { Native to Asia }\end{array}$ & $\begin{array}{l}\mathrm{N} \\
\mathrm{N}\end{array}$ \\
\hline Cyperus alulatus J. Kern & RRLH54630 & $\mathrm{H}$ & A & Jun-Jul & Forest slopes & THP & & NP & Elliptic & LC & $\begin{array}{l}\text { Native to the Indian } \\
\text { subcontinent }\end{array}$ & $\mathrm{N}$ \\
\hline Carex brunnea Thunb. & RRLH55270 & $\mathrm{H}$ & $\mathrm{P}$ & Jun-Jul & $\begin{array}{l}\text { Mountain } \\
\text { slopes }\end{array}$ & $\mathrm{HCP}$ & & $\mathrm{NP}$ & Lanceolate & NA & Native to Africa & $\mathrm{E}$ \\
\hline Carex muricata $\mathrm{L}$. & RRLH55271 & $\mathrm{H}$ & $\mathrm{P}$ & May-Jun & Hill slopes & $\mathrm{HCP}$ & & MIC & Lanceolate & NA & $\begin{array}{l}\text { Native to North } \\
\text { America }\end{array}$ & $\mathrm{E}$ \\
\hline Cyperus niveus Retz. & RRLH54667 & $\mathrm{H}$ & $\mathrm{A}$ & Sep-Oct & $\begin{array}{l}\text { Stream } \\
\text { margins }\end{array}$ & THP & & MIC & Elliptic & NA & Native to Asia & $\mathrm{N}$ \\
\hline
\end{tabular}


Table 5. Cont

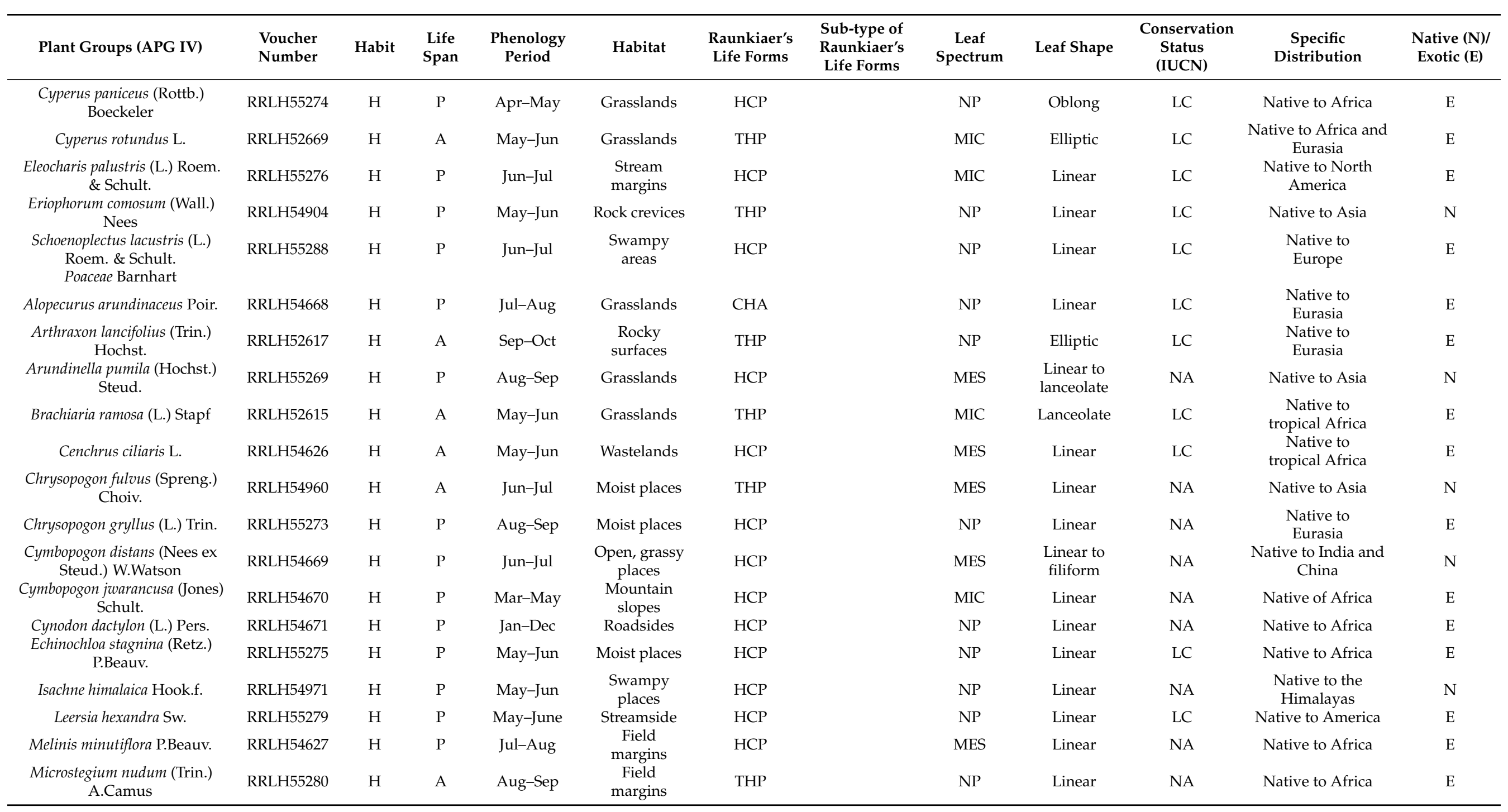


Table 5. Cont.

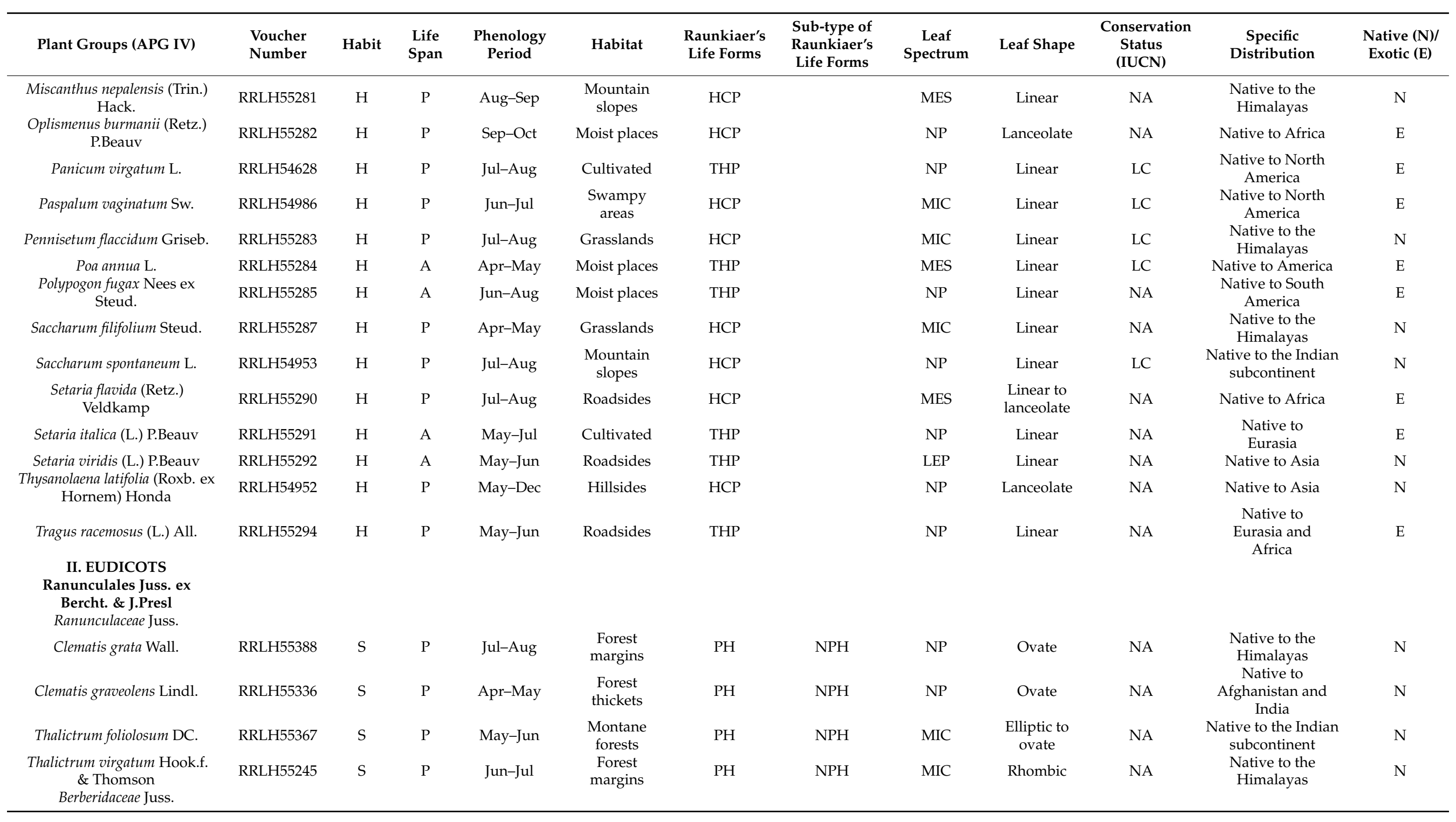


Table 5. Cont.

\begin{tabular}{|c|c|c|c|c|c|c|c|c|c|c|c|c|}
\hline Plant Groups (APG IV) & $\begin{array}{l}\text { Voucher } \\
\text { Number }\end{array}$ & Habit & $\begin{array}{l}\text { Life } \\
\text { Span }\end{array}$ & $\begin{array}{l}\text { Phenology } \\
\text { Period }\end{array}$ & Habitat & $\begin{array}{l}\text { Raunkiaer's } \\
\text { Life Forms }\end{array}$ & $\begin{array}{l}\text { Sub-type of } \\
\text { Raunkiaer's } \\
\text { Life Forms }\end{array}$ & $\begin{array}{c}\text { Leaf } \\
\text { Spectrum }\end{array}$ & Leaf Shape & $\begin{array}{l}\text { Conservation } \\
\text { Status } \\
\text { (IUCN) }\end{array}$ & $\begin{array}{c}\text { Specific } \\
\text { Distribution }\end{array}$ & $\begin{array}{l}\text { Native (N)/ } \\
\text { Exotic (E) }\end{array}$ \\
\hline Berberis lycium Royle & RRLH55359 & S & $\mathrm{P}$ & Apr-May & $\begin{array}{l}\text { Forest } \\
\text { margins }\end{array}$ & PH & $\mathrm{NPH}$ & NP & Oblanceolate & NA & $\begin{array}{l}\text { Native to the } \\
\text { Himalayas }\end{array}$ & $\mathrm{N}$ \\
\hline $\begin{array}{l}\text { Platanaceae T.Lestib. } \\
\text { Platanus orientalis L. }\end{array}$ & RRLH55215 & $\mathrm{T}$ & $\mathrm{P}$ & Mar-May & Cultivated & $\mathrm{PH}$ & $\mathrm{MPH}$ & $\mathrm{NP}$ & Ovate & DD & $\begin{array}{l}\text { Native to } \\
\text { Europe }\end{array}$ & E \\
\hline $\begin{array}{l}\text { Buxales Takht. ex Reveal } \\
\text { Buxaceae Dumort. } \\
\text { Sarcococca saligna (D.Don) } \\
\text { Müll.Arg. } \\
\text { Papaveraceae Juss. }\end{array}$ & RRLH55268 & S & $\mathrm{P}$ & May-Jun & $\begin{array}{l}\text { Evergreen } \\
\text { forests }\end{array}$ & $\mathrm{PH}$ & NPH & MES & Lanceolate & NA & $\begin{array}{l}\text { Native to India and } \\
\text { Pakistan }\end{array}$ & $\mathrm{N}$ \\
\hline $\begin{array}{l}\text { Argemone mexicana L. } \\
\text { Menispermaceae Juss. }\end{array}$ & RRLH54671 & $\mathrm{H}$ & $\mathrm{A}$ & Mar-Apr & Streamside & THP & & MIC & Oblanceolate & NA & $\begin{array}{l}\text { Native to North } \\
\text { America }\end{array}$ & E \\
\hline Cissampelos pareira $\mathrm{L}$. & RRLH54662 & S & $\mathrm{P}$ & Mar-Apr & $\begin{array}{c}\text { Forest } \\
\text { margins }\end{array}$ & $\mathrm{PH}$ & NPH & NP & Ovate & NA & Native to Asia & $\mathrm{N}$ \\
\hline $\begin{array}{c}\text { Tinospora cordifolia (Willd.) } \\
\text { Hook.f. \& Thomson } \\
\text { Piperales Bercht. \& J.Presl } \\
\text { Piperaceae Giseke }\end{array}$ & RRLH54670 & S & $\mathrm{P}$ & May-Jun & $\begin{array}{l}\text { Forest } \\
\text { thickets }\end{array}$ & $\mathrm{PH}$ & NPH & MES & Cordate & NA & Native to Asia & $\mathrm{N}$ \\
\hline $\begin{array}{c}\text { Neolitsea umbrosa (Nees) } \\
\text { Gamble }\end{array}$ & RRLH54992 & $\mathrm{T}$ & $\mathrm{P}$ & Mar-May & $\begin{array}{l}\text { Forest } \\
\text { margins }\end{array}$ & PH & $\mathrm{MPH}$ & MES & Oblong & NA & $\begin{array}{l}\text { Native to the } \\
\text { Himalayas }\end{array}$ & $\mathrm{N}$ \\
\hline $\begin{array}{l}\text { III. CORE EUDICOTS } \\
\text { SUPERROSIDS } \\
\text { Saxifragales Bercht. \& J. } \\
\text { Presl } \\
\text { Crassulaceae J.St.-Hil. }\end{array}$ & & & & & & & & & & & & \\
\hline $\begin{array}{l}\text { Rosularia adenotricha (Wall. ex } \\
\text { Edgew.) C.-A.Jansson } \\
\text { Fabales Bromhead } \\
\text { Fabaceae Lindl. }\end{array}$ & RRLH54904 & $\mathrm{H}$ & $\mathrm{A}$ & May-Jun & Rock crevices & THP & & MIC & Obovate & NA & $\begin{array}{l}\text { Native to the } \\
\text { Himalayas }\end{array}$ & $\mathrm{N}$ \\
\hline Acacia concinna (Willd.) DC. & RRLH54925 & S & $\mathrm{P}$ & April-Jun & $\begin{array}{l}\text { Forest } \\
\text { thickets }\end{array}$ & $\mathrm{PH}$ & $\mathrm{NPH}$ & MIC & Ovate & NA & Native to Asia & $\mathrm{N}$ \\
\hline $\begin{array}{c}\text { Albizia chinensis (Osbeck) } \\
\text { Merr. }\end{array}$ & RRLH54675 & $\mathrm{T}$ & $\mathrm{P}$ & Mar-May & Open areas & $\mathrm{PH}$ & $\mathrm{MPH}$ & MIC & Oblong & NA & $\begin{array}{c}\text { Native to Southeast } \\
\text { Asia }\end{array}$ & $\mathrm{N}$ \\
\hline
\end{tabular}


Table 5. Cont.

\begin{tabular}{|c|c|c|c|c|c|c|c|c|c|c|c|c|}
\hline Plant Groups (APG IV) & $\begin{array}{l}\text { Voucher } \\
\text { Number }\end{array}$ & Habit & $\begin{array}{l}\text { Life } \\
\text { Span }\end{array}$ & $\begin{array}{l}\text { Phenology } \\
\text { Period }\end{array}$ & Habitat & $\begin{array}{l}\text { Raunkiaer's } \\
\text { Life Forms }\end{array}$ & $\begin{array}{c}\text { Sub-type of } \\
\text { Raunkiaer's } \\
\text { Life Forms }\end{array}$ & $\begin{array}{c}\text { Leaf } \\
\text { Spectrum }\end{array}$ & Leaf Shape & $\begin{array}{l}\text { Conservation } \\
\text { Status } \\
\text { (IUCN) }\end{array}$ & $\begin{array}{c}\text { Specific } \\
\text { Distribution }\end{array}$ & $\begin{array}{l}\text { Native (N)/ } \\
\text { Exotic (E) }\end{array}$ \\
\hline $\begin{array}{c}\text { Argyrolobium roseum } \\
\text { (Cambess.) Jaub. \& Spach }\end{array}$ & RRLH55372 & $\mathrm{H}$ & A & May-Jun & $\begin{array}{l}\text { Forest } \\
\text { margins }\end{array}$ & THP & & MIC & Obovate & NA & $\begin{array}{l}\text { Native to India and } \\
\text { Pakistan }\end{array}$ & $\mathrm{N}$ \\
\hline Bauhinia purpurea L. & RRLH55373 & $\mathrm{T}$ & $\mathrm{P}$ & May-Jun & Cultivated & PH & $\mathrm{MPH}$ & MIC & Suborbicular & $\mathrm{LC}$ & $\begin{array}{l}\text { Native to the Indian } \\
\text { subcontinent }\end{array}$ & $\mathrm{N}$ \\
\hline $\begin{array}{c}\text { Biancaea decapetela (Roth.) } \\
\text { O.Deg. }\end{array}$ & RRLH55374 & S & $\mathrm{P}$ & Apr-May & Roadsides & $\mathrm{PH}$ & $\mathrm{NPH}$ & MIC & Ovate & NA & Native to Asia & $\mathrm{N}$ \\
\hline $\begin{array}{c}\text { Butea monosperma (Lam.) } \\
\text { Kuntze }\end{array}$ & RRLH54676 & $\mathrm{T}$ & $\mathrm{P}$ & Mar-Apr & $\begin{array}{l}\text { Forest } \\
\text { margins }\end{array}$ & $\mathrm{PH}$ & $\mathrm{MPH}$ & $\mathrm{NP}$ & Obovate & $\mathrm{LC}$ & Native to Asia & $\mathrm{N}$ \\
\hline Cassia fistula $\mathrm{L}$. & RRLH55375 & $\mathrm{T}$ & $\mathrm{P}$ & Aug-Sep & Roadsides & $\mathrm{PH}$ & MGP & MES & Ovate & $\mathrm{LC}$ & $\begin{array}{l}\text { Native to the Indian } \\
\text { subcontinent }\end{array}$ & $\mathrm{N}$ \\
\hline $\begin{array}{l}\text { Chamaecrista mimosoides (L.) } \\
\text { Greene }\end{array}$ & RRLH55611 & S & $\mathrm{P}$ & Apr-May & Wastelands & $\mathrm{PH}$ & $\mathrm{NPH}$ & MEG & Linear & $\mathrm{LC}$ & Native to Africa & $\mathrm{E}$ \\
\hline Dalbergia sissoo Roxb. ex DC. & RRLH54931 & $\mathrm{T}$ & $\mathrm{P}$ & Mar-Apr & Cultivated & $\mathrm{PH}$ & $\mathrm{MPH}$ & MEG & Ovate & LC & Native to India & $\mathrm{N}$ \\
\hline $\begin{array}{c}\text { Delonix regia (Bojer ex Hook.) } \\
\text { Raf. }\end{array}$ & RRLH55375 & $\mathrm{T}$ & $\mathrm{P}$ & Jun-Jul & Cultivated & $\mathrm{PH}$ & $\mathrm{MPH}$ & $\mathrm{NP}$ & Oblong & $\mathrm{LC}$ & $\begin{array}{c}\text { Native to } \\
\text { Madagascar }\end{array}$ & $\mathrm{E}$ \\
\hline Erythrina indica Lam. & RRLH55376 & $\mathrm{T}$ & $\mathrm{P}$ & Apr-May & $\begin{array}{l}\text { Field } \\
\text { margins }\end{array}$ & $\mathrm{PH}$ & $\mathrm{MPH}$ & MES & Lanceolate & $\mathrm{LC}$ & $\begin{array}{c}\text { Native to Africa and } \\
\text { Asia }\end{array}$ & $\mathrm{N}$ \\
\hline $\begin{array}{c}\text { Grona triflora (L.) H.Ohashi \& } \\
\text { K.Ohashi }\end{array}$ & RRLH54905 & S & $\mathrm{P}$ & May-Jun & $\begin{array}{l}\text { Forest } \\
\text { thickets }\end{array}$ & $\mathrm{PH}$ & $\mathrm{NPH}$ & MIC & Obovate & NA & Native to America & $\mathrm{E}$ \\
\hline $\begin{array}{l}\text { Ototropis multiflora (DC.) H. } \\
\text { Ohashi \& K. Ohashi }\end{array}$ & RRLH55363 & S & $\mathrm{P}$ & Jul-Aug & $\begin{array}{l}\text { Mountain } \\
\text { slopes }\end{array}$ & $\mathrm{PH}$ & $\mathrm{NPH}$ & MIC & Elliptic & NA & $\begin{array}{l}\text { Native to the Indian } \\
\text { subcontinent }\end{array}$ & $\mathrm{N}$ \\
\hline $\begin{array}{c}\text { Phyllodium elegans (Lour.) } \\
\text { Desv. }\end{array}$ & RRLH54987 & S & $\mathrm{P}$ & May-Jun & $\begin{array}{l}\text { Forest } \\
\text { thickets }\end{array}$ & $\mathrm{PH}$ & $\mathrm{NPH}$ & NP & Ovate & $\mathrm{LC}$ & $\begin{array}{l}\text { Native to the } \\
\text { Himalayas }\end{array}$ & $\mathrm{N}$ \\
\hline Robinia pseudoacacia L. & RRLH54602 & $\mathrm{T}$ & $\mathrm{P}$ & May-Jun & Cultivated & $\mathrm{PH}$ & $\mathrm{MPH}$ & MES & Oblong & $\mathrm{LC}$ & $\begin{array}{c}\text { Native to North } \\
\text { America }\end{array}$ & $\mathrm{E}$ \\
\hline $\begin{array}{l}\text { Senegalia modesta (Wall.) } \\
\text { P.J.H.Hurter }\end{array}$ & RRLH54674 & $\mathrm{T}$ & $\mathrm{P}$ & Mar-May & Cultivated & $\mathrm{PH}$ & MPH & MES & Ovate & NA & $\begin{array}{l}\text { Native to the Indian } \\
\text { subcontinent }\end{array}$ & $\mathrm{N}$ \\
\hline \multicolumn{13}{|l|}{ Rosales Bercht. \& J.Presl } \\
\hline Cannabis sativa $\mathrm{L}$. & RRLH54915 & $\mathrm{H}$ & $\mathrm{A}$ & May-Jun & Wastelands & THP & & $\mathrm{NP}$ & Lanceolate & NA & $\begin{array}{l}\text { Native to Asia } \\
\text { Native to the }\end{array}$ & $\mathrm{N}$ \\
\hline Celtis australis $\mathrm{L}$. & RRLH55360 & $\mathrm{T}$ & $\mathrm{P}$ & Mar-May & $\begin{array}{l}\text { Field } \\
\text { margins }\end{array}$ & $\mathrm{PH}$ & MPH & $\mathrm{NP}$ & Ovate & $\mathrm{LC}$ & $\begin{array}{c}\text { Mediterranean } \\
\text { region and West } \\
\text { Asia }\end{array}$ & E \\
\hline $\begin{array}{c}\text { Elaeagnaceae Juss. } \\
\text { Elaeagnus umbellata Thunb. } \\
\text { Rosaceae Juss. }\end{array}$ & RRLH55354 & $\mathrm{T}$ & $\mathrm{P}$ & Apr-May & $\begin{array}{l}\text { Forest } \\
\text { thickets }\end{array}$ & $\mathrm{PH}$ & $\mathrm{MPH}$ & MIC & Obovate & $\mathrm{LC}$ & Native to Asia & $\mathrm{N}$ \\
\hline
\end{tabular}


Table 5. Cont.

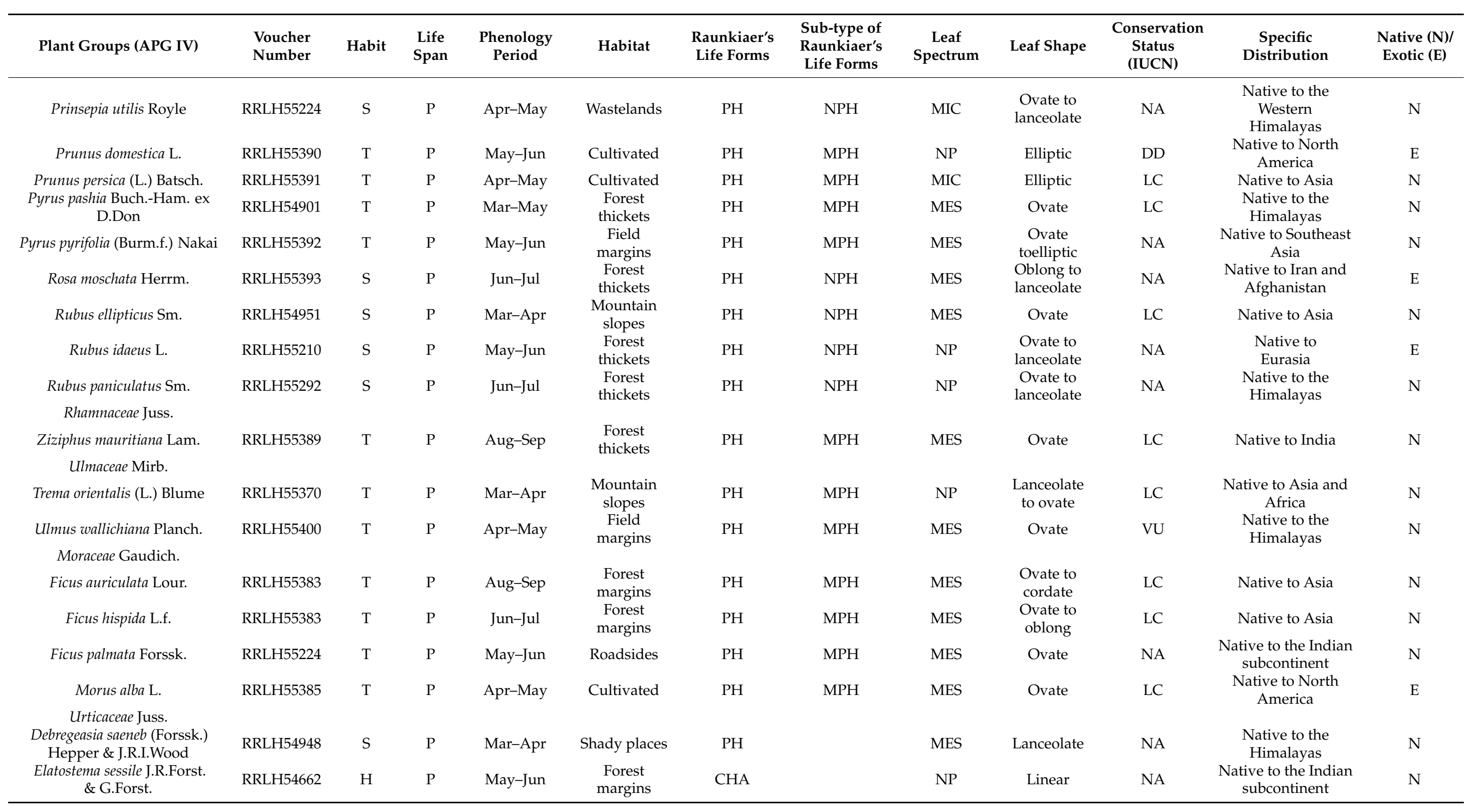


Table 5. Cont.

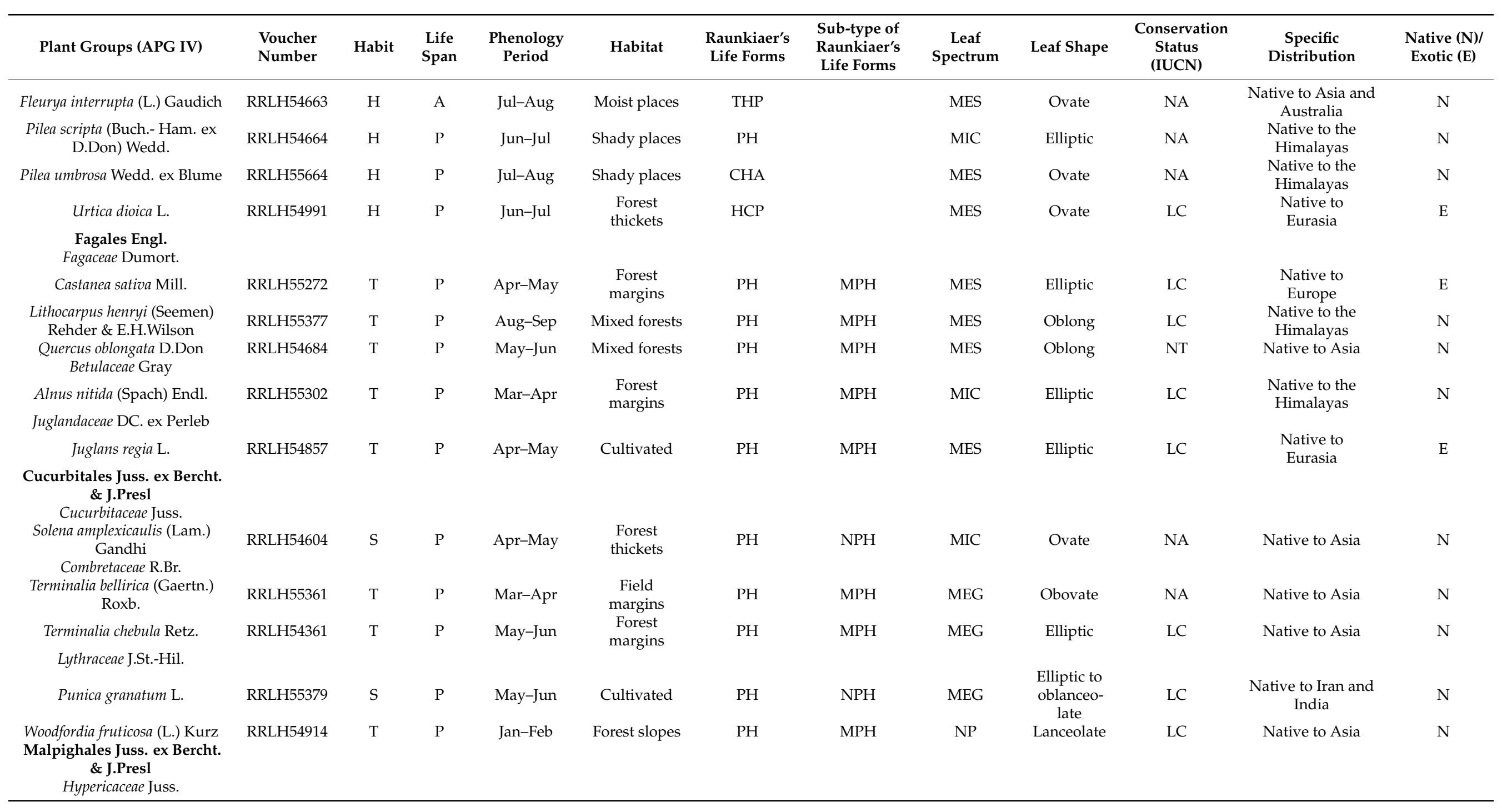


Table 5. Cont.

\begin{tabular}{|c|c|c|c|c|c|c|c|c|c|c|c|c|}
\hline Plant Groups (APG IV) & $\begin{array}{l}\text { Voucher } \\
\text { Number }\end{array}$ & Habit & $\begin{array}{l}\text { Life } \\
\text { Span }\end{array}$ & $\begin{array}{l}\text { Phenology } \\
\text { Period }\end{array}$ & Habitat & $\begin{array}{l}\text { Raunkiaer's } \\
\text { Life Forms }\end{array}$ & $\begin{array}{l}\text { Sub-type of } \\
\text { Raunkiaer's } \\
\text { Life Forms }\end{array}$ & $\begin{array}{c}\text { Leaf } \\
\text { Spectrum }\end{array}$ & Leaf Shape & $\begin{array}{l}\text { Conservation } \\
\text { Status } \\
\text { (IUCN) }\end{array}$ & $\begin{array}{c}\text { Specific } \\
\text { Distribution }\end{array}$ & $\begin{array}{l}\text { Native (N)/ } \\
\text { Exotic (E) }\end{array}$ \\
\hline Hypericum perforatum $\mathrm{L}$. & RRLH54665 & $\mathrm{H}$ & $\mathrm{P}$ & Jun-Jul & $\begin{array}{l}\text { Grassland } \\
\text { slopes }\end{array}$ & $\mathrm{PH}$ & & $\mathrm{NP}$ & Oblong & NA & $\begin{array}{l}\text { Native to } \\
\text { Eurasia }\end{array}$ & E \\
\hline $\begin{array}{l}\text { Violaceae Batsch. } \\
\text { Viola odorata } \mathrm{L} . \\
\text { Euphorbiaceae Juss. }\end{array}$ & RRLH55218 & $\mathrm{H}$ & $\mathrm{P}$ & Apr-May & Forest Slopes & THP & & NP & Ovate & NA & Native to Asia & $\mathrm{N}$ \\
\hline Euphorbia hirsuta L. & RRLH54944 & $\mathrm{H}$ & A & Jun-Jul & Roadsides & $\mathrm{HCP}$ & & MIC & $\begin{array}{l}\text { Lanceolate } \\
\text { to ovate }\end{array}$ & NA & Native to India & $\mathrm{N}$ \\
\hline Triadica sebifera (L.) Small & RRLH55371 & $\mathrm{T}$ & $P$ & May-Jun & Forest slopes & $\mathrm{PH}$ & $\mathrm{MPH}$ & $\mathrm{NP}$ & $\begin{array}{l}\text { Rhomboid } \\
\text { to ovate }\end{array}$ & $\mathrm{LC}$ & $\begin{array}{l}\text { Native to China and } \\
\text { Taiwan }\end{array}$ & $\mathrm{E}$ \\
\hline $\begin{array}{c}\text { Salicaceae Mirb. } \\
\text { Flacourtia indica (Burm.f.) } \\
\text { Merr. }\end{array}$ & RRLH55395 & S & $\mathrm{P}$ & Jan-Feb & Mixed forests & $\mathrm{PH}$ & $\mathrm{NPH}$ & MEG & Oblong & $\mathrm{LC}$ & $\begin{array}{c}\text { Native to Africa and } \\
\text { Asia }\end{array}$ & $\mathrm{N}$ \\
\hline Populus ciliata Wall. ex Royle & RRLH55396 & $\mathrm{T}$ & $\mathrm{P}$ & May-Jun & Roadsides & $\mathrm{PH}$ & $\mathrm{MPH}$ & MES & Ovate & $\mathrm{LC}$ & $\begin{array}{l}\text { Native to the } \\
\text { Himalayas }\end{array}$ & $\mathrm{N}$ \\
\hline Xylosma longifolia Clos & RRLH55397 & $\mathrm{T}$ & $\mathrm{P}$ & Apr-May & $\begin{array}{l}\text { Mountain } \\
\text { forests }\end{array}$ & $\mathrm{PH}$ & $\mathrm{MPH}$ & MES & Elliptic & $\mathrm{LC}$ & $\begin{array}{l}\text { Native to the Indian } \\
\text { subcontinent }\end{array}$ & $\mathrm{N}$ \\
\hline $\begin{array}{c}\text { Sapindales Juss. } \\
\text { Sapindaceae Juss. } \\
\text { Aesculus indica (Wall. ex } \\
\text { Cambess.) Hook. }\end{array}$ & RRLH55368 & $\mathrm{T}$ & $\mathrm{P}$ & Apr-May & $\begin{array}{l}\text { Field } \\
\text { margins }\end{array}$ & $\mathrm{PH}$ & $\mathrm{MPH}$ & MEG & Oblong & $\mathrm{LC}$ & $\begin{array}{l}\text { Native to the } \\
\text { Himalayas }\end{array}$ & $\mathrm{N}$ \\
\hline $\begin{array}{c}\text { Acer caesium Wall. ex Brandis } \\
\text { Rutaceae Juss. }\end{array}$ & RRLH42643 & $\mathrm{T}$ & $\mathrm{P}$ & May-Jun & $\begin{array}{l}\text { Forest } \\
\text { margins }\end{array}$ & $\mathrm{PH}$ & $\mathrm{MPH}$ & MEG & Obovate & $\mathrm{LC}$ & $\begin{array}{l}\text { Native to the } \\
\text { Himalayas }\end{array}$ & $\mathrm{N}$ \\
\hline Murraya koenigii (L.) Spreng. & RRLH52649 & S & $\mathrm{P}$ & Mar-Apr & Mixed forests & $\mathrm{PH}$ & $\mathrm{NPH}$ & MES & Ovate & NA & $\begin{array}{l}\text { Native to India and } \\
\text { Sri Lanka }\end{array}$ & $\mathrm{N}$ \\
\hline Aegle marmelos (L.) Corrêa & RRLH52641 & $\mathrm{T}$ & $\mathrm{P}$ & Jul-Aug & Mixed forests & $\mathrm{PH}$ & MPH & MES & Ovate & NT & $\begin{array}{l}\text { Native to the Indian } \\
\text { subcontinent }\end{array}$ & $\mathrm{N}$ \\
\hline $\begin{array}{c}\text { Zanthoxylum armatum DC. } \\
\text { Anacardiaceae } \mathrm{R} . B r .\end{array}$ & RRLH55226 & $\mathrm{T}$ & $\mathrm{P}$ & Apr-May & $\begin{array}{l}\text { Forest } \\
\text { margins }\end{array}$ & $\mathrm{PH}$ & $\mathrm{MPH}$ & MIC & Lanceolate & $\mathrm{LC}$ & $\begin{array}{l}\text { Native to the } \\
\text { Himalayas }\end{array}$ & $\mathrm{N}$ \\
\hline $\begin{array}{l}\text { Cotinus coggygria Scop. } \\
\text { Simaroubaceae DC. }\end{array}$ & RRLH54912 & $\mathrm{T}$ & $\mathrm{P}$ & Feb-mar & $\begin{array}{l}\text { Forest } \\
\text { thickets }\end{array}$ & $\mathrm{PH}$ & $\mathrm{MPH}$ & MIC & Elliptic & $\mathrm{LC}$ & $\begin{array}{l}\text { Native to } \\
\text { Eurasia }\end{array}$ & E \\
\hline $\begin{array}{c}\text { Ailanthus altissima (Mill.) } \\
\text { Swingle } \\
\text { Meliaceae Juss. }\end{array}$ & RRLH55398 & $\mathrm{T}$ & $\mathrm{P}$ & Apr-May & Mixed forests & $\mathrm{PH}$ & $\mathrm{MPH}$ & MEG & Ovate & EN & Native to Asia & $\mathrm{N}$ \\
\hline Melia azedarach L. & RRLH55382 & $\mathrm{T}$ & $\mathrm{P}$ & Mar-Apr & $\begin{array}{l}\text { Field } \\
\text { margins }\end{array}$ & $\mathrm{PH}$ & $\mathrm{MPH}$ & MIC & Ovate & LC & Native to Asia & $\mathrm{N}$ \\
\hline
\end{tabular}


Table 5. Cont.

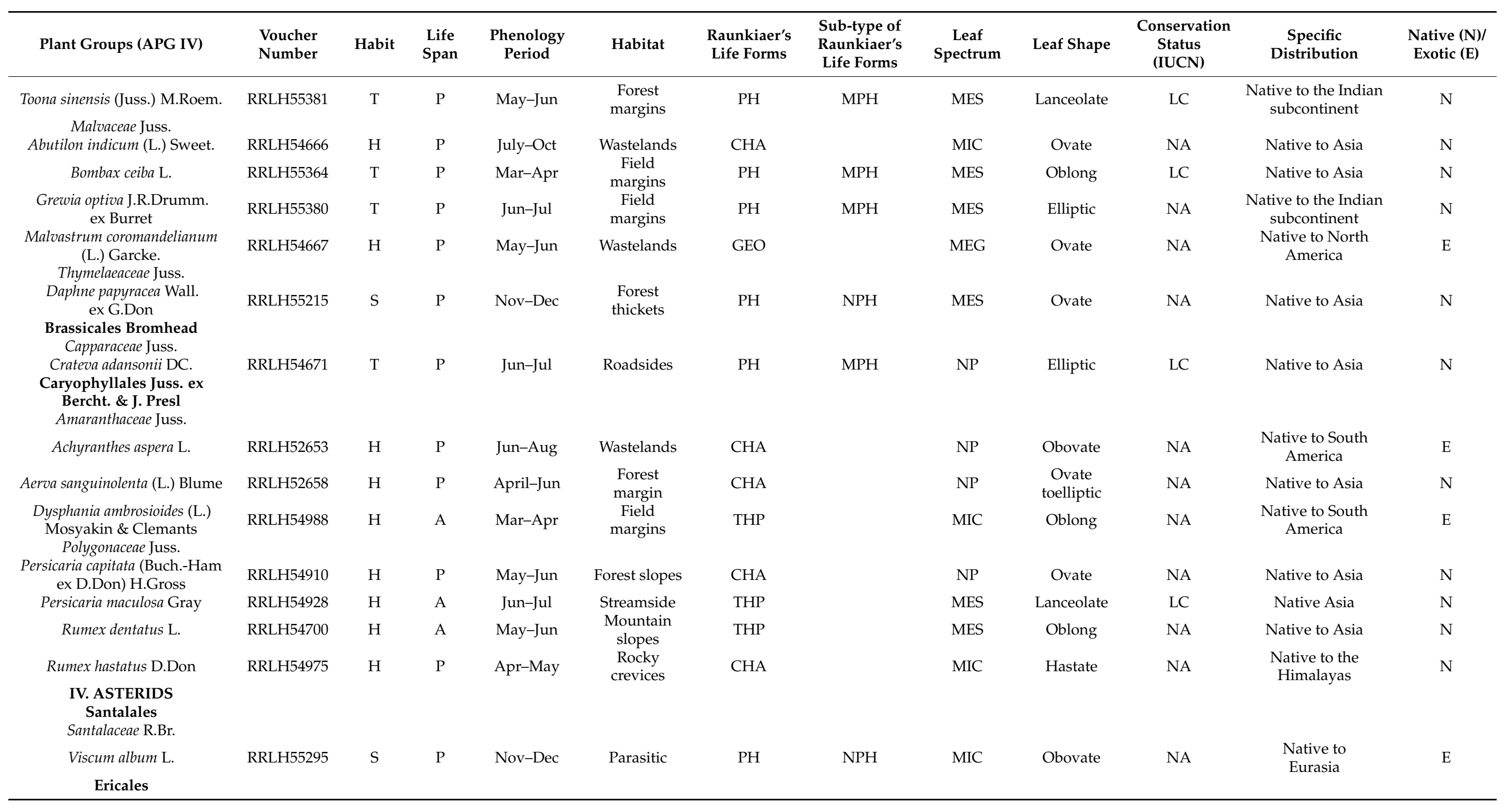


Table 5. Cont.

\begin{tabular}{|c|c|c|c|c|c|c|c|c|c|c|c|c|}
\hline Plant Groups (APG IV) & $\begin{array}{l}\text { Voucher } \\
\text { Number }\end{array}$ & Habit & $\begin{array}{l}\text { Life } \\
\text { Span }\end{array}$ & $\begin{array}{l}\text { Phenology } \\
\text { Period }\end{array}$ & Habitat & $\begin{array}{l}\text { Raunkiaer's } \\
\text { Life Forms }\end{array}$ & $\begin{array}{l}\text { Sub-type of } \\
\text { Raunkiaer's } \\
\text { Life Forms }\end{array}$ & $\begin{array}{c}\text { Leaf } \\
\text { Spectrum }\end{array}$ & Leaf Shape & $\begin{array}{l}\text { Conservation } \\
\text { Status } \\
\text { (IUCN) }\end{array}$ & $\begin{array}{c}\text { Specific } \\
\text { Distribution }\end{array}$ & $\begin{array}{l}\text { Native }(\mathrm{N}) / \\
\text { Exotic (E) }\end{array}$ \\
\hline \multicolumn{13}{|l|}{ Ericaceae Durande } \\
\hline Lyonia ovalifolia (Wall.) Drude. & RRLH55355 & $\mathrm{T}$ & $P$ & May-Jun & $\begin{array}{l}\text { Forest } \\
\text { thickets }\end{array}$ & $\mathrm{PH}$ & $\mathrm{MPH}$ & MES & Ovate & $\mathrm{LC}$ & $\begin{array}{l}\text { Native to the } \\
\text { Himalayas }\end{array}$ & $\mathrm{N}$ \\
\hline $\begin{array}{l}\text { Rhododendron arboreum Sm. } \\
\text { Primulaceae Batsch ex Borkh. }\end{array}$ & RRLH55204 & $\mathrm{T}$ & $\mathrm{P}$ & May-Jun & Forest slopes & $\mathrm{PH}$ & $\mathrm{MPH}$ & MES & Oblong & LC & Native to Asia & $\mathrm{N}$ \\
\hline $\begin{array}{l}\text { Lysimachia arvensis (L.) } \\
\text { U.Manns \& Anderb. } \\
\text { Gentianales Juss. ex Bercht. } \\
\text { \& J.Presl } \\
\text { Rubiaceae Juss. }\end{array}$ & RRLH55387 & $\mathrm{H}$ & $\mathrm{A}$ & May-Jun & Wastelands & THP & & MEG & Ovate & NA & Native to Asia & $\mathrm{N}$ \\
\hline Galium asperuloides Edgew. & RRLH55213 & $\mathrm{H}$ & $\mathrm{P}$ & Apr-May & $\begin{array}{l}\text { Mountain } \\
\text { slopes }\end{array}$ & $\mathrm{CHA}$ & & MIC & Elliptic & NA & $\begin{array}{l}\text { Native to the Indian } \\
\text { subcontinent }\end{array}$ & $\mathrm{N}$ \\
\hline Galium aparine $\mathrm{L}$. & RRLH55394 & $\mathrm{H}$ & $\mathrm{A}$ & Mar-Apr & $\begin{array}{l}\text { Forest } \\
\text { thickets }\end{array}$ & THP & & MIC & Linear & NA & $\begin{array}{l}\text { Native to South } \\
\text { America and Eurasia }\end{array}$ & $\mathrm{E}$ \\
\hline Rubia cordifolia L. & RRLH54625 & $\mathrm{H}$ & A & Aug-Sep & $\begin{array}{l}\text { Forest } \\
\text { margins }\end{array}$ & THP & & $\mathrm{NP}$ & Lanceolate & NA & Native to India & $\mathrm{N}$ \\
\hline $\begin{array}{c}\text { Apocynaceae Juss. } \\
\text { Holarrhena antidysenterica } \\
\text { Wall. } \\
\text { Boraginaceae Juss. }\end{array}$ & RRLH52631 & $\mathrm{T}$ & $\mathrm{P}$ & Apr-Jul & Mixed forests & $\mathrm{PH}$ & $\mathrm{MPH}$ & MEG & Ovate & $\mathrm{LC}$ & Native to India & $\mathrm{N}$ \\
\hline Cordia dichotoma G. Forst. & RRLH52610 & $\mathrm{T}$ & $\mathrm{P}$ & Feb-Mar & $\begin{array}{l}\text { Field } \\
\text { margins }\end{array}$ & $\mathrm{PH}$ & MPH & MEG & Ovate & LC & Native to India & $\mathrm{N}$ \\
\hline \multicolumn{5}{|l|}{$\begin{array}{c}\text { Solanales Juss. ex Bercht. \& } \\
\text { J.Presl } \\
\text { Convolvulaceae Juss. }\end{array}$} & Mixed forests & $\mathrm{PH}$ & $\mathrm{NPH}$ & MES & Cordate & NA & $\begin{array}{l}\text { Native to the Indian } \\
\text { subcontinent }\end{array}$ & $\mathrm{N}$ \\
\hline Solanum americanum Mill. & RRLH54619 & $\mathrm{H}$ & A & Nov-Dec & Wastelands & THP & & MES & Ovate & NA & $\begin{array}{c}\text { Native to North } \\
\text { America }\end{array}$ & $\mathrm{E}$ \\
\hline Solanum virginianum $\mathrm{L}$. & RRLH54927 & $\mathrm{H}$ & $\mathrm{A}$ & Oct-Dec & Moist places & THP & & MES & $\begin{array}{l}\text { Ovate to } \\
\text { oblong }\end{array}$ & NA & $\begin{array}{l}\text { Native to the Indian } \\
\text { subcontinent }\end{array}$ & $\mathrm{N}$ \\
\hline Solanum xanthocarpum Schrad. & RRLH52367 & $\mathrm{H}$ & $\mathrm{P}$ & Nov-Dec & Moist places & THP & & MES & Ovate & LC & $\begin{array}{l}\text { Native to the Indian } \\
\text { subcontinent }\end{array}$ & $\mathrm{N}$ \\
\hline \multicolumn{13}{|l|}{$\begin{array}{l}\text { Lamiales Bromhead } \\
\text { Oleaceae Hoffmanns. \& Link }\end{array}$} \\
\hline $\begin{array}{c}\text { Syringa emodi Wall. ex Royle } \\
\text { Plantaginaceae Juss. }\end{array}$ & RRLH55386 & $\mathrm{T}$ & $\mathrm{P}$ & May-Jun & Mixed forests & $\mathrm{PH}$ & $\mathrm{MPH}$ & MES & Ovate & NA & $\begin{array}{l}\text { Native to the } \\
\text { Himalayas }\end{array}$ & $\mathrm{N}$ \\
\hline Plantago lanceolata $\mathrm{L}$. & RRLH55365 & $\mathrm{H}$ & $\mathrm{P}$ & May-Jun & Wastelands & $\mathrm{HCP}$ & & MES & Lanceolate & VU & $\begin{array}{c}\text { Native to } \\
\text { Eurasia to Asia }\end{array}$ & $\mathrm{N}$ \\
\hline
\end{tabular}


Table 5. Cont.

\begin{tabular}{|c|c|c|c|c|c|c|c|c|c|c|c|c|}
\hline Plant Groups (APG IV) & $\begin{array}{l}\text { Voucher } \\
\text { Number }\end{array}$ & Habit & $\begin{array}{l}\text { Life } \\
\text { Span }\end{array}$ & $\begin{array}{l}\text { Phenology } \\
\text { Period }\end{array}$ & Habitat & $\begin{array}{l}\text { Raunkiaer's } \\
\text { Life Forms }\end{array}$ & $\begin{array}{l}\text { Sub-type of } \\
\text { Raunkiaer's } \\
\text { Life Forms }\end{array}$ & $\begin{array}{c}\text { Leaf } \\
\text { Spectrum }\end{array}$ & Leaf Shape & $\begin{array}{l}\text { Conservation } \\
\text { Status } \\
\text { (IUCN) }\end{array}$ & $\begin{array}{c}\text { Specific } \\
\text { Distribution }\end{array}$ & $\begin{array}{l}\text { Native (N)/ } \\
\text { Exotic (E) }\end{array}$ \\
\hline $\begin{array}{l}\text { Acanthaceae Juss. } \\
\text { Barleria cristata L. }\end{array}$ & RRLH52605 & $\mathrm{H}$ & $\mathrm{P}$ & May-Jun & Forest slopes & $\mathrm{CHA}$ & & MES & Elliptic & NA & Native to Asia & $\mathrm{N}$ \\
\hline Dicliptera bupleuroides Nees & RRLH52611 & $\mathrm{H}$ & A & Jun-Jul & Roadsides & THP & & $\mathrm{NP}$ & Ovate & NA & Native to Asia & $\mathrm{N}$ \\
\hline Justicia adhatoda L. & RRLH52653 & $\mathrm{H}$ & $\mathrm{P}$ & Jan-Feb & Roadsides & $\mathrm{PH}$ & & MES & $\begin{array}{l}\text { Ovate } \\
\text { toelliptic }\end{array}$ & NA & $\begin{array}{l}\text { Native to the Indian } \\
\text { subcontinent }\end{array}$ & $\mathrm{N}$ \\
\hline Lepidagathis cuspidata Nees & RRLH52619 & $\mathrm{H}$ & $\mathrm{P}$ & Mar-May & $\begin{array}{l}\text { Forest } \\
\text { thickets }\end{array}$ & $\mathrm{CHA}$ & & MES & Elliptic & NA & Native to India & $\mathrm{N}$ \\
\hline $\begin{array}{c}\text { Strobilanthes wallichii Nees } \\
\text { Lamiaceae Martinov }\end{array}$ & RRLH54997 & S & $\mathrm{P}$ & Jun-Jul & Open forests & $\mathrm{PH}$ & NPH & NP & Elliptic & NA & $\begin{array}{l}\text { Native to the } \\
\text { Himalayas }\end{array}$ & $\mathrm{N}$ \\
\hline Colebrookea oppositifolia Sm. & RRLH54908 & S & $\mathrm{P}$ & Jan-Mar & $\begin{array}{l}\text { Forest } \\
\text { thickets }\end{array}$ & $\mathrm{PH}$ & NPH & NP & Oblong & NA & $\begin{array}{l}\text { Native to the Indian } \\
\text { subcontinent }\end{array}$ & $\mathrm{N}$ \\
\hline $\begin{array}{c}\text { Isodon japonicus (Burm.f.) } \\
\text { H.Hara }\end{array}$ & RRLH55224 & S & $\mathrm{P}$ & Jul-Aug & $\begin{array}{l}\text { Forest } \\
\text { thickets }\end{array}$ & $\mathrm{PH}$ & NPH & NP & Ovate & NA & Native to Asia & $\mathrm{N}$ \\
\hline $\begin{array}{l}\text { Isodon rugosus (Wall. ex } \\
\text { Benth.) Codd }\end{array}$ & RRLH55225 & $\mathrm{S}$ & $\mathrm{P}$ & Jul-Aug & $\begin{array}{l}\text { Forest } \\
\text { thickets }\end{array}$ & $\mathrm{PH}$ & NPH & MEG & Ovate & NA & Native to Asia & $\mathrm{N}$ \\
\hline Leucas ciliata Benth. & RRLH54903 & $\mathrm{H}$ & $P$ & Jul-Oct & Roadsides & THP & & NP & Lanceolate & NA & Native to Asia & $\mathrm{N}$ \\
\hline $\begin{array}{l}\text { Scutellaria discolor Wall. } \\
\text { ex Benth. }\end{array}$ & RRLH55289 & $\mathrm{H}$ & $\mathrm{P}$ & Jun-Jul & $\begin{array}{l}\text { Forest } \\
\text { margins }\end{array}$ & $\mathrm{CHA}$ & & MES & $\begin{array}{l}\text { Elliptic to } \\
\text { ovate }\end{array}$ & NA & $\begin{array}{l}\text { Native to the } \\
\text { Himalayas }\end{array}$ & $\mathrm{N}$ \\
\hline Vitex negundo L. & RRLH55378 & S & $\mathrm{P}$ & Apr-May & $\begin{array}{l}\text { Forest } \\
\text { thickets }\end{array}$ & $\mathrm{PH}$ & $\mathrm{NPH}$ & NP & Lanceolate & $\mathrm{LC}$ & $\begin{array}{c}\text { Native to Asia and } \\
\text { Africa }\end{array}$ & $\mathrm{N}$ \\
\hline $\begin{array}{l}\text { Scrophulariaceae Juss. } \\
\text { Buddleja paniculata Wall. }\end{array}$ & RRLH55369 & S & $\mathrm{P}$ & Mar-Apr & $\begin{array}{l}\text { Forest } \\
\text { thickets }\end{array}$ & $\mathrm{PH}$ & NPH & MES & Elliptic & NA & Native to Asia & $\mathrm{N}$ \\
\hline $\begin{array}{l}\text { Asterales Link } \\
\text { Asteraceae Bercht. \& J.Presl }\end{array}$ & & & & & & & & & & & & \\
\hline Ageratum conyzoides L. & RRLH55357 & $\mathrm{H}$ & $\mathrm{A}$ & Jan-Dec & $\begin{array}{l}\text { Field } \\
\text { margins }\end{array}$ & THP & & NP & Ovate & NA & $\begin{array}{l}\text { Native to South } \\
\text { America } \\
\text { Native to the }\end{array}$ & E \\
\hline $\begin{array}{l}\text { Bidens biternata (Lour.) Merr. } \\
\text { \& Sherff }\end{array}$ & RRLH54650 & $\mathrm{H}$ & A & Sep-Oct & Roadsides & THP & & $\mathrm{NP}$ & Ovate & NA & $\begin{array}{l}\text { tropical and } \\
\text { subtropical Old } \\
\text { World }\end{array}$ & E \\
\hline Elephantopus scaber L. & RRLH55258 & $\mathrm{H}$ & A & Jul-Aug & $\begin{array}{l}\text { Forest } \\
\text { margins }\end{array}$ & THP & & MES & Oblanceolate & NA & $\begin{array}{l}\text { Native to the Indian } \\
\text { subcontinent }\end{array}$ & $\mathrm{N}$ \\
\hline Galinsoga parviflora Cav. & RRLH54630 & $\mathrm{H}$ & A & Jul-Aug & $\begin{array}{l}\text { Field } \\
\text { margins }\end{array}$ & THP & & MIC & Elliptic & NA & $\begin{array}{l}\text { Native to South } \\
\text { America }\end{array}$ & E \\
\hline Gynura angulosa (Wall.) DC. & RRLH54609 & $\mathrm{H}$ & $\mathrm{P}$ & Sep-Oct & Forest slopes & $\mathrm{CHA}$ & & NP & Obovate & NA & Native to Asia & $\mathrm{N}$ \\
\hline
\end{tabular}


Table 5. Cont.

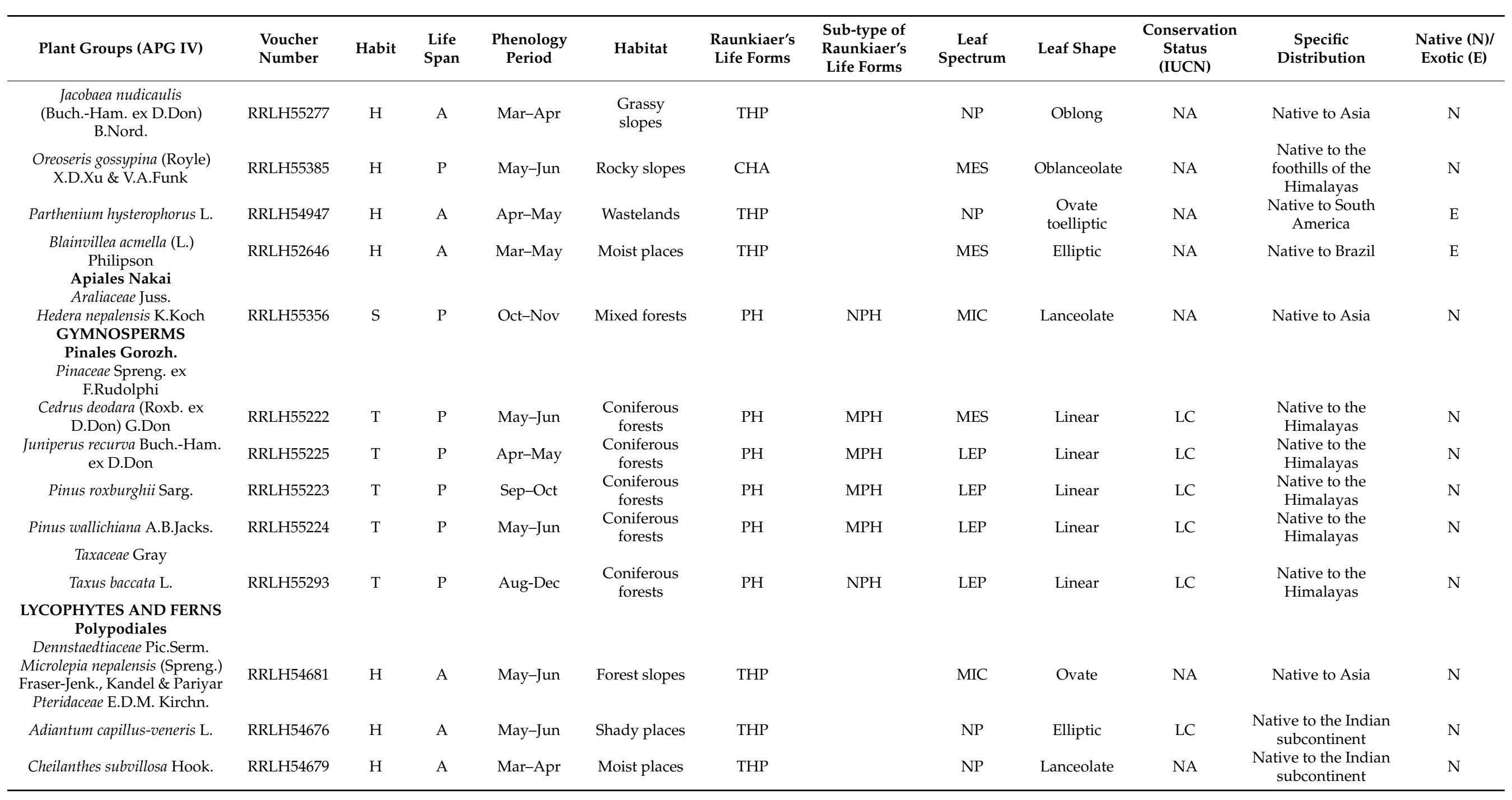


Table 5. Cont.

\begin{tabular}{|c|c|c|c|c|c|c|c|c|c|c|c|c|}
\hline Plant Groups (APG IV) & $\begin{array}{l}\text { Voucher } \\
\text { Number }\end{array}$ & Habit & $\begin{array}{l}\text { Life } \\
\text { Span }\end{array}$ & $\begin{array}{l}\text { Phenology } \\
\text { Period }\end{array}$ & Habitat & $\begin{array}{l}\text { Raunkiaer's } \\
\text { Life Forms }\end{array}$ & $\begin{array}{l}\text { Sub-type of } \\
\text { Raunkiaer's } \\
\text { Life Forms }\end{array}$ & $\begin{array}{c}\text { Leaf } \\
\text { Spectrum }\end{array}$ & Leaf Shape & $\begin{array}{l}\text { Conservation } \\
\text { Status } \\
\text { (IUCN) }\end{array}$ & $\begin{array}{c}\text { Specific } \\
\text { Distribution }\end{array}$ & $\begin{array}{c}\text { Native (N)/ } \\
\text { Exotic (E) }\end{array}$ \\
\hline $\begin{array}{l}\text { Onychium japonicum } \\
\text { (Thunb.) Kunze }\end{array}$ & RRLH54682 & $\mathrm{H}$ & $\mathrm{A}$ & May-Jun & Moist places & THP & & MIC & Ovate & NA & Native to Asia & $\mathrm{N}$ \\
\hline $\begin{array}{l}\text { Polystichum polyblepharum } \\
\text { (Roem. ex Kunze) C.Presl }\end{array}$ & RRLH54683 & $\mathrm{H}$ & $\mathrm{P}$ & Mar-Apr & Shady places & $\mathrm{HCP}$ & & LEP & Lanceolate & NA & $\begin{array}{l}\text { Native to North and } \\
\text { South America }\end{array}$ & $\mathrm{E}$ \\
\hline Pteris cretica $\mathrm{L}$. & RRLH54684 & $\mathrm{H}$ & $\mathrm{P}$ & Mar-Apr & $\begin{array}{c}\text { Forest } \\
\text { margins }\end{array}$ & $\mathrm{HCP}$ & & MES & Obovate & NA & $\begin{array}{l}\text { Native to Africa and } \\
\text { Eurasia }\end{array}$ & E \\
\hline Pteris vittata $\mathrm{L}$. & RRLH54685 & $\mathrm{H}$ & $\mathrm{P}$ & Mar-Apr & $\begin{array}{l}\text { Forest } \\
\text { margins }\end{array}$ & $\mathrm{HCP}$ & & MES & Elliptic & $\mathrm{LC}$ & Native to Asia & $\mathrm{N}$ \\
\hline $\begin{array}{c}\text { Aspleniaceae Newman } \\
\text { Asplenium adiantum-nigrum L. }\end{array}$ & RRLH54677 & $\mathrm{H}$ & A & May-Jun & $\begin{array}{l}\text { Rocky } \\
\text { crevices }\end{array}$ & THP & & LEP & Ovate & NA & $\begin{array}{l}\text { Native to } \\
\text { Eurasia }\end{array}$ & E \\
\hline $\begin{array}{l}\text { Asplenium dalhousiae Hook. } \\
\text { Selaginellaceae Willk. }\end{array}$ & RRLH54678 & $\mathrm{H}$ & A & May-Jun & $\begin{array}{l}\text { Rocky } \\
\text { surfaces }\end{array}$ & THP & & $\mathrm{NP}$ & Ovate & NA & Native to India & $\mathrm{N}$ \\
\hline Selaginella eurynota A.Br. & RRLH54686 & $\mathrm{H}$ & A & Mar-Apr & Shady places & THP & & LEP & $\begin{array}{l}\text { Elliptic to } \\
\text { ovate }\end{array}$ & NA & Native to Asia & $\mathrm{N}$ \\
\hline
\end{tabular}

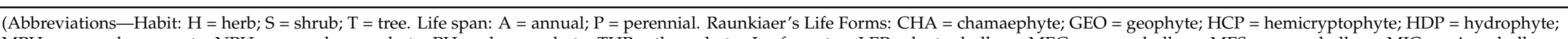

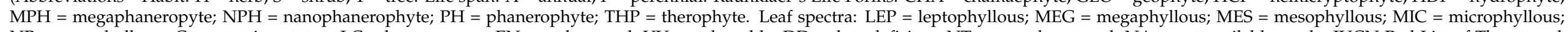

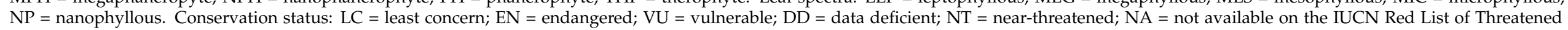
Species'website/not assessed. Nativeness: $\mathrm{E}=$ exotic; $\mathrm{N}=$ native/indigenous). 


\section{Conclusions}

Scientific findings have proven that floristic analysis is a good indicator of the ecological wealth of the ecosystem within the given setup of the prevailing microhabitat conditions of a particular geographical region. The inventory of the floristic composition of India and elsewhere in the world would help in bridging the geographical knowledge gaps in invasion biology research. The inventory can serve as a scientific baseline for investigating the patterns, pathways, extent, impacts, and effective management of plant invasions in India. Studying floristic composition and associated ecological parameters in the Himalayas is a necessity for biodiversity conservation, because it provides scientific data pertaining tothe environment for wildlife, and simultaneously contributes to the sustainable management of unique regional natural resources. The Bani Valley in the Northwestern Himalayan Region is floristically abundant with natural resources, which is evident from the occurrence of 196 different species of plants. The surprising levels of diversity recorded in the subtropical and temperate forest plots, as well as the low levels of similarity between these forests, suggest that the Bani Valley may harbor forests richer in plant species than previously imagined. More extensive explorations and inventories throughout the Himalayan regions are needed in order to get a better idea of just how diverse these forests may be. Analysis of life forms gives a clear picture of the biological spectrum of the Bani Valley, which in times to come will serve as baseline information for ecologists and environmentalists. In the present study, phanerophytes, therophytes, and hemicryptophytes share importance in depicting the "phanero-thero-hemicrypto phytic"phytoclimate. This study can provide baseline data for use by policymakers and wildlife departments to develop conservation plans for the sustainable use of plant resources in the Himalayas, particularly for the subtropical and temperate species. It also suggests that biotic factors play an important role in shaping the vegetation of a landscape; therefore, anthropogenic stress can be minimized. Accordingly, we suggest that rich-diversity forests such as those found in the Bani Valley should be given higher priority in conservation planning than is presently the case. Finally, it is worthwhile to point out that the Bani Valley is rather close to several indigenous communities, which therefore means that these areas are inhabited, exploited, and intervened in by humans, although such impacts are very low. In times to come, conservation programs could be started in order to protect economically valuable flora by educating the native communities residing there.

Author Contributions: Conceptualization, B.S. (Bikarma Singh) and C.M.M.; data curation, S.S., O.S., M.N.B., B.S. (Bishander Singh) and C.M.M.; formal analysis, S.S. and B.S. (Bikarma Singh); investigation, S.S.; methodology, S.S. and B.S. (Bikarma Singh); supervision, B.S. (Bikarma Singh); validation, O.S., M.N.B., B.S. (Bishander Singh) and C.M.M.; visualization, B.S. (Bikarma Singh) and C.M.M.; writing—original draft, S.S.; writing—review and editing, S.S., B.S. (Bikarma Singh) and C.M.M. All authors have read and agreed to the published version of the manuscript.

Funding: This research received no external funding.

Institutional Review Board Statement: Not applicable.

Informed Consent Statement: Not applicable.

Data Availability Statement: First time generated during the study and presented in this article.

Acknowledgments: The authors are thankful to the Head of the Department of Botany at Veer Kunwar Singh University, Ara, Bihar, and to the Directors of CSIR-IIIM Jammu and CSIR-NBRI Lucknow for providing herbarium facilities and moral support. The authors acknowledge the local people for revealing their traditional knowledge, and the J\&K Forest Department for support in survey and exploration. Authors are thankful to AcSIR, Ghaziabad for affiliation and registration in the PhD program.

Conflicts of Interest: The authors declare no conflict of interest. 


\section{References}

1. Odum, E.P. Ecology and Our Endangered Life-Support Systems; Sinaur Associates, Inc.: Sunderland, MA, USA, 1993.

2. Tang, Z.Y.; Fang, J.Y. A Review on the Elevational Patterns of Plant Species Diversity. Biodivers. J. 2004, 12, 20-28.

3. Rahbek, C. The Role of Spatial Scale and the Perception of Large-scale Species-richness Patterns. Ecol. Lett. 2004, 8, 224-239. [CrossRef]

4. Xu, W.; Xiao, Y.; Zhang, J.; Yang, W.; Zhang, L.; Hull, V.; Wang, Z.; Zheng, H.; Liu, J.; Polasky, S.; et al. Strengthening Protected Areas for Biodiversity and Ecosystem Services in China. Proc. Natl. Acad. Sci. USA 2017, 114, 1601-1606. [CrossRef]

5. Fuentes, J.C.P.; Cano-Ortiz, A.; Musarella, C.M.; Canas, R.Q.; Gomes, C.J.P.; Spampinato, G.; Del Río, S.; Cano, E. Bioclimatology, Structure, and Conservation Perspectives of Quercus pyrenaica, Acer opalus subsp. granatensis, and Corylus avellana Deciduous Forests on Mediterranean Bioclimate in the South-Central Part of the Iberian Peninsula. Sustainability 2019, 11, 6500. [CrossRef]

6. Fang, J.Y. Exploring Altitudinal Patterns of Plant Diversity of China's Mountains. Biodivers. J. 2004, 12, 1-4.

7. Sen, U.K.; Bhakat, R.K. Floristic and Phytoclimatic Study of a Sacred Grove Vegetation of West Midnapore District, West Bengal, India. J. Trop. Life Sci. 2019, 9, 119-138. [CrossRef]

8. Adhikari, D.; Tiwari, R.; Singh, P.P.; Upadhay, K.; Singh, B.; Haridasan, K.E.; Bhatt, B.B.; Chetri, A.; Barik, S.K. Ecological Niche Modeling as a Cumulative Environmental Impact Assessment Tool for Biodiversity Assessment and Conservation Planning a Case Study of Critically Endangered Plant Lagerstroemia minuticarpa in Indian Eastern Himalaya. J. Environ. Manag. 2019, 243, 299-307.

9. Muller, D.; Ellenberg, H. Aims and Methods of Vegetation Ecology; The Blackburn Press: Caldwell, NJ, USA, 1974.

10. Singh, B.; Singh, B.; Borthakur, S.K.; Phukan, S.J. Contribution to Himalayan Hotspot: Assessment of Forest Types, Floristic Composition and Economic Wealth of Nokrek Biosphere Reserve in Northeast India. Indian Forest. 2018, 144, $734-741$.

11. Warming, E.; Balfour, I.B.; Groom, P.; Vahl, M. Oecology of Plants: An Introduction to the Study of Plant-Communities; Smithsonian Institution: Washington, DC, USA, 1909.

12. Dansereau, P.; Guinochet, M.; Tomaselli, R. Two New European Commentaries on Phytosociology. Ecology 1957, 38 , 364. [CrossRef]

13. Singh, B.; Singh, B.; Singh, S.; Bhanwaria, R.; Chandra, S. Biological Spectrum and Floral Diversity of Western Himalaya-A Case Study of Nandini Wildlife Sanctuary in J\&K State. In Angiopserm Systematics: Recent Trends and Emerging Issues; Agnihotri, P., Khuraijam, J.S., Eds.; Bishen Singh Mahendra Pal Singh Press: Dehradun, India, 2018; pp. 589-605.

14. Raunkiaer, C. The Life Forms of Plants and Statistical Plant Geography; Clarendon Press: Oxford, UK, 1934.

15. Da Costa, R.C.; de Araujo, F.S.; Lima-Verde, L.W. Flora and Life-Form Spectrum in an Area of Deciduous Thorn Woodland (Caatinga) in Northeastern, Brazil. J. Arid. Environ. 2007, 68, 237-247. [CrossRef]

16. Al-Yemeni, M.; Sher, S. Biological Spectrum with More Other Ecological Attributes of the Flora and Vegetation of the Asir Mountain of South West, Saudi Arabia. Afr. J. Biotech. 2010, 9, 5550-5559.

17. Batalha, M.A.; Martins, F.R. Floristic, Frequency, and Vegetation Life-Form Spectra of a Cerrado Site. Braz. J. Biol. 2004, 64, 201-209. [CrossRef]

18. Badshah, L.; Hussain, F.; Sher, Z. Floristic Inventory, Ecological Characteristics and Biological Spectrum of Plants of Parachinar, Kurram Agency, Pakistan. Pak. J. Bot. 2016, 48, 1547-1558.

19. Box, E.O. Macroclimate and Plant Forms: An Introduction to Predictive Modeling in Phytogeography; Dr. W. Junk: The Hague, The Netherlands, 1981.

20. Gillison, A.N. Latitudinal Variation in Plant Functional Types. In Geographical Changes in Vegetation and Functional Types; Greller, A.M., Fujiwara, K., Pedrotti, F., Eds.; Springer: Cham, Switzerland, 2018; pp. 21-57.

21. Cain, S.A.; Castro, G.D.O. Manual of Vegetation Analysis; Harper and Brothers: New York, NY, USA, 1959.

22. Meher-Homji, V.M. Life Forms and Biological Spectra as Epharmonic Criteria of Aridity and Humidity in Tropics. J. Indian Bot. Soc. 1964, 43, 424-430.

23. Rana, T.S.; Datt, B.; Rao, R.R. Life Forms and Biological Spectrum of the Flora of Tons Valley, Garhwal Himalaya (Uttaranchal), India. Taiwania 2002, 47, 164-169.

24. El-Ghani, M.M.; Amer, W.M. Soil-Vegetation Relationships in a Coastal Desert Plain of Southern Sinai, Egypt. J. Arid. Environ. 2003, 55, 607-628. [CrossRef]

25. Austin, M.P. The Potential Contribution of Vegetation Ecology to Biodiversity Research. Ecography 1999, 22, 465-484. [CrossRef]

26. Körner, C. Mountain Biodiversity, Its Causes and Function. Ambio 2004, 13, 11-17. [CrossRef]

27. Ricklefs, R.E.; Lovette, I.J. The Roles of Island Area per se and Habitat Diversity in the Species-Area Relationships of Four Lesser Antillean Faunal Groups. J. Anim. Ecol. 1999, 68, 1142-1160. [CrossRef]

28. Kalmar, A.; Currie, D.J. A Global Model of Island Biogeography. Glob. Ecol. Biogeogr. 2006, 15, 72-81. [CrossRef]

29. Musarella, C.M.; Brullo, S.; Del Galdo, G.G. Contribution to the Orophilous Cushion-Like Vegetation of Central-Southern and Insular Greece. Plants 2020, 9, 1678. [CrossRef] [PubMed]

30. Grabherr, G.; Gottfried, M.; Pauli, H. Climate Effects on Mountain Plants. Nat. Cell Biol. 1994, 369, 448. [CrossRef] [PubMed]

31. Grabherr, G.; Gottfried, M.; Pauli, H. Long-term Monitoring of Mountain Peaks in the Alps. In Biomonitoring: General and Applied Aspects on Regional and Global Scales; Burga, C.A., Kratochwil, A., Eds.; Kluwer: Amsterdam, The Netherlands, 2001 ; pp. $153-177$.

32. Beniston, M. Climatic Change in Mountain Regions: A Review of Possible Impacts. Clim. Chang. 2003, 59, 5-31. [CrossRef]

33. Boom, B.M. A Forest Inventory in Amazonian Bolivia. Biotropica 1986, 18, 287. [CrossRef] 
34. Rosati, L.; Romano, V.A.; Bartolucci, F.; Bernardo, L.; Bouvet, D.; Cancellieri, L.; Caruso, G.; Conti, F.; Faraoni, F.; Banfi, E.; et al. Contribution to the Floristic Knowledge of the Maddalena Mountains (Basilicata and Campania, Southern Italy). Ital. Bot. 2017, 3, 73-82. [CrossRef]

35. Pérez-García, F.J.; Medina-Cazorla, J.M.; Martínez-Hernández, F.; Garrido-Becerra, J.A.; Mendoza-Fernández, A.J.; Salmerón Sánchez, E.; Mota, J.F. The Baetic Endemic Flora: Taxonomic Structure, Ecological and Rarity Patterns. Implications for a Conservation Policy. Ann. Bot. Fenn. 2012, 49, 43-54. [CrossRef]

36. Resource Partner on Biodiversity. ENVIS Center on Biological Diversity. Available online: http://www.bsienvis.nic.in (accessed on 20 August 2020).

37. Ashutosh, S.; Pandey, S.; Kaur, T.; Bajpai, R.K. Knowledge Based Remote Sensing and GIS Approach for Forest Type Mapping in Kathua District, Jammu and Kashmir. Trop. Ecol. 2010, 51, 21-29.

38. Kumari, S.; Batish, D.R.; Singh, H.P.; Negi, K.; Kohli, R.K. An Ethnobotanical Survey of Medicinal Plants Used by Gujjar Community of Trikutta Hills in Jammu and Kashmir, India. J. Med. Plant Res. 2013, 7, 2111-2121.

39. Thakur, S.; Dutt, H.C.; Singh, B.; Sharma, Y.P.; Tashi, N.; Charak, R.S.; Sharma, G.; Vidyarathi, O.P.; Iqbal, T.; Singh, B.; et al. Plant and Fungi Diversity of Devi Pindiyan Valley in Trikuta Hills of Northwestern Himalaya, India. J. Threat. Taxa 2019, 11, 14827-14844. [CrossRef]

40. Singh, B. Swertia patnitopiansis, a New Species of Gentianaceae from North-Western Himalaya, India. Phytotaxa 2021, 498, 273-280. [CrossRef]

41. Singh, B.; Sultan, P.; Bedi, Y.S. Juniperus chinensis L. (Cupressaceae): A New Taxa Record for Himalaya and Extension of Geographic Distribution in South Asia. Natl. Acad. Sci. Lett. 2018, 41, 69-73. [CrossRef]

42. Singh, B.; Singh, S.; Singh, B. New Distribution Records of the Leopard Plants Ligularia amplexicaulis DC. and Ligularia sibirica (L.) Cass. (Asteraceae) in the Indian Himalaya. J. Threat. Taxa 2018, 10, 12854-12858. [CrossRef]

43. Malik, A.H.; Khuroo, A.A.; Dar, G.H.; Khan, Z.S. An Annotated Inventory of Arboreal Flora in Jammu and Kashmir State. Bioprospecting 2020, 18, 565-606. [CrossRef]

44. Singh, B.; Singh, B.; Kishor, A.; Singh, S.; Bhat, M.N.; Surmal, O.; Musarella, C.M. Exploring Plant-Based Ethnomedicine and Quantitative Ethnopharmacology: Medicinal Plants Utilized by the Population of Jasrota Hill in Western Himalaya. Sustainability 2020, 12, 7526. [CrossRef]

45. Champion, H.G.; Seth, S.K. A Revised Survey of Forest Types of India; The Manager Publication of India: New Delhi, India, 1968.

46. Whittaker, R.H. Dominance and Diversity in Land Plant Communities: Numerical Relations of Species Express the Importance of Competition in Community Function and Evolution. Science 1965, 147, 250-260. [CrossRef] [PubMed]

47. Mori, S.A.; Boom, B.M.; De Carvalho, A.M.; Dos Santos, T.S. Southern Bahian Moist Forests. Bot. Rev. 1983, 49, 155-232. [CrossRef]

48. Greig-Smith, P. Quantitative Plant Ecology, 3rd ed.; University of California Press: Berkeley, CA, USA, 1983.

49. Magurran, A.E. Ecological Diversity and Its Measurement; Princeton University Press: Princeton, NJ, USA, 1988.

50. Gentry, A.H. Tree Species Richness of Upper Amazonian Forests. Proc. Natl. Acad. Sci. USA 1988, 85, 156-159. [CrossRef] [PubMed]

51. Milliken, W. Structure and Composition of One Hectare of Central Amazonian Terra Firme Forest. Biotropica 1998, 30, 530-537. [CrossRef]

52. Jain, S.K.; Rao, R.R. A Handbook of Field and Herbarium Methods; Today and Tomorrow's Printer Publisher: New Delhi, India, 1977.

53. Thiers, B. Index Herbariorum: A Global Directory of Public Herbaria and Associated Staff. New York Botanical Garden's Virtual Herbarium 2020. Available online: http:/ / sweetgum.nybg.org/science/ih (accessed on 12 August 2020).

54. The Angiosperm Phylogeny Group. An Update of the Angiosperm Phylogeny Group Classification for the Orders and Families of Flowering Plants: APG IV. Bot. J. Linn. Soc. 2016, 181, 1-20. [CrossRef]

55. Swami, A.; Gupta, R.K. Flora of Udhampur; Bishen Singh Mahendra Pal Singh: Dehradun, India, 1998; pp. 306-312.

56. Sharma, B.M.; Kachroo, P. Flora of Jammu and Plants of Neighbourhood; Bishen Singh Mahendra Pal Singh: Dehradun, India, 1981.

57. Kapur, S.K.; Sarin, Y.K. Flora of Trikuta Hills; Bishen Singh Mahendra Pal Singh: Dehradun, India, 1990.

58. Duke, J.A. Handbook of Medicinal Herbs; CRC Press: London, UK, 2002.

59. Sharma, B.M. Illustration of Jammu Plants; Bishen Singh Mahendra Pal Singh: Dehradun, India, 2010.

60. Dar, G.H.; Khuroo, A.A. Floristic Diversity in the Kashmir Himalaya: Progress, Problem and Prospects. Sains Malaysiana 2013, 42, 1377-1386.

61. Sharma, P.; Rana, J.C.; Devi, U.; Randhawa, S.S.; Kumar, R. Floristic Diversity and Distribution Pattern of Plant Communities along Altitudinal Gradient in Sangla Valley, Northwest Himalaya. Sci. World J. 2014, 1-11. [CrossRef]

62. Chawla, A.; Rajkumar, S.; Singh, K.N.; Lal, B.; Singh, R.D.; Thukral, A.K. Plant Species Diversity along an Altitudinal Gradient of Bhabha Valley in Western Himalaya. J. Mt. Sci. 2008, 5, 157-177. [CrossRef]

63. Chowdhery, H.J.; Wadhwa, B.M. Flora of Himachal Pradesh; Botanical Survey of India: Calcutta, India, 1984 ; pp. 1-3.

64. Zent, E.L.; Zent, S. Floristic Composition, Structure, and Diversity of Four Forest Plots in the Sierra Maigualida, Venezuelan Guayana. Biodivers. Conserv. 2004, 13, 2453-2483. [CrossRef]

65. Agrawal, A.K. Floristic Composition and Phenology of Temperate Grasslands of Western Himalaya as Affected by Scraping, Fire and Heavy Grazing. Vegetatio 1990, 88, 177-187. [CrossRef]

66. Shaheen, H.; Ullah, Z.; Khan, S.M.; Harper, D.M. Species Composition and Community Structure of Western Himalayan Moist Temperate Forests in Kashmir. Forest. Ecol. Manag. 2012, 278, 138-145. [CrossRef] 
67. Haq, S.M.; Malik, A.H.; Khuroo, A.A.; Rashid, I. Floristic Composition and Biological Spectrum of Keran-A Remote Valley of Northwestern Himalaya. Acta Ecol. Sin. 2019, 39, 372-379. [CrossRef]

68. Dhaliwal, D.S.; Sharma, M. Flora of Kullu District (Himachal Pradesh); Bishen Singh Mahendra Pal Singh Publisher: Dehradun, India, 1999.

69. Haq, S.M.; Hamid, M.; Lone, F.A.; Singh, B. Himalayan Hotspot with Alien Weeds: A Case Study of Biological Spectrum, Phenology, and Diversity of Weedy Plants of High Altitude Mountains in District Kupwara of J\&K Himalaya, India. Proc. Natl. Acad. Sci. India Sect. B Boil. Sci. 2021, 91, 139-152. [CrossRef]

70. Mir, N.A.; Masood, T.H.; Sofi, P.A.; Husain, M.; Rather, T.A. Life form Spectrum of Vegetation in Betula Dominant Tree Stands along the Available Altitudinal Gradient in North-western Himalayas of Kashmir. Res. Rev. J. Pharmacogn. Phytochem. 2017, 6, 267-272.

71. Dogra, K.S.; Sood, S.K.; Sharma, R. Distribution, Biology and Ecology of Parthenium hysterophorus L. (Congress Grass) an Invasive Species in the North-western Indian Himalaya (Himachal Pradesh). Acad. J. 2011, 5, 682-687.

72. Gaston, A.; Garson, P.; Hunter, M. The Status and Conservation of Forest Wildlife in Himachal Pradesh, Western Himalayas. Biol. Conserv. 1983, 27, 291-314. [CrossRef]

73. Gairola, S.; Sharma, C.M.; Suyal, S.; Ghildiyal, S.K. Composition and Diversity of Five Major Forest Types in Moist Temperate Climate of the Western Himalayas. For. Stud. China 2011, 13, 139-153. [CrossRef]

74. Subramani, S.P.; Jishtu, V.; Verma, R.K.; Kapoor, K.S. Floristic Composition, Life-Forms and Biological Spectrum of Renuka Wildlife Sanctuary. Indian Forest. 2007, 133, 79-92.

75. Saha, S. Determination of Life Form Patterns in the Singalila Range of Darjeeling. Environ. Ecol. 2008, 26, 588-590.

76. Rawat, G.S.; Adhikari, B.S. Floristics and Distribution of Plant Communities across Moisture and Topographic Gradients in Tso Kar Basin, Changthang Plateau, Eastern Ladakh. Arctic Antarct. Alp. Res. 2005, 37, 539-544. [CrossRef]

77. Namgail Gopal, T.; Rawat, G.S.; Mishra, C.; Van Wieren, S.E.; Prins, H.H.T. Biomass and Diversity of Dry Alpine Plant Communities Along Altitudinal Gradients in the Himalayas. J. Plant Res. 2011, 125, 93-101. [CrossRef]

78. Klimes, L. Life-Forms and Clonality of Vascular Plants Along an Altitudinal Gradient in Eastern Ladakh (NW Himalayas). Basic Appl. Ecol. 2013, 4, 317-318. [CrossRef]

79. Pharswan, K.; Mehta, J.P.; Subodh. Floristic Composition and Biological Spectrum of Vegetation in Alpine Meadows of Kedarnath: Garhwal Himalaya. Nat. Sci. 2010, 7, 109-115.

80. Nautiyal, M.C.; Nautiyal, B.P.; Prakash, V. Phenology and Growth Form Distribution in an Alpine Pasture at Tungnath, Garhwal, Himalaya. Mt. Res. Dev. 2001, 21, 168-174. [CrossRef]

81. Johnston, M.; Gilman, M. Tree Population Studies in Low Diversity Forests, Guyana. I. Floristic Composition and Stand Structure. Biodivers. Conserv. 1995, 4, 339-362. [CrossRef]

82. Clark, D.B.; Clark, D.A. Abundance, Growth and Mortality of Very Large Trees in Neotropical Lowland Rain Forest. Forest Ecol. Manag. 1996, 80, 235-244. [CrossRef]

83. Saxena, A.K.; Pandey, P.; Singh, J.S. Biological Spectrum and Other Structural Functional Attributes of the Vegetation of Kumaun Himalaya. Vegetatio 1982, 49, 111-119. [CrossRef]

84. Singh, B.; Bedi, Y.S. Eating from Raw Wild Plants in Himalaya: Traditional Knowledge Documentary on Sheena Tribe along LOC Border in Kashmir. Indian J. Nat. Prod. Resour. 2017, 8, 269-275.

85. Das, D.S.; Rawat, D.S.; Maity, D.; Dash, S.S.; Sinha, B.K. Species Richness Patterns of Different Life-Forms along Altitudinal Gradients in the Great Himalayan National Park, Western Himalaya, India. Taiwania 2020, 65, 154-162.

86. Wright, I.J.; Dong, N.; Maire, V.; Prentice, I.C.; Westoby, M.; Diaz, S.; Gallagher, R.V.; Jacobs, B.F.; Kooyman, R.; Law, E.A.; et al. Global Climatic Drivers of Leaf Size. Science 2017, 357, 917-921. [CrossRef]

87. Shaheen, H.; Khan, S.M.; Harper, D.M.; Ullah, Z.; Qureshi, R.A. Species Diversity, Community Structure, and Distribution Patterns in Western Himalayan Alpine Pastures of Kashmir, Pakistan. Mt. Res. Dev. 2011, 31, 153. [CrossRef]

88. Prance, G.T. Discovering the Plant World. Taxon 2001, 50, 345-359. [CrossRef]

89. Kala, C.P. Phenology of Alpine Plants in the Valley of Flowers National Park and Hemkund, Western Himalaya. Indian Forest. 1999, 125, 581-590.

90. Pangtey, Y.P.S.; Rawal, R.S.; Bankoti, N.S.; Samant, S.S. Phenology of High-altitude Plants of Kumaun in Central Himalaya, India. Int. J. Biometeorol. 1990, 34, 122-127. [CrossRef]

91. Bisht, V.K.; Kuniyal, C.P.; Bhandari, A.K.; Nautiyal, B.P.; Prasad, P. Phenology of Plants in Relation to Ambient Environment in a Subalpine Forest of Uttarakhand, Western Himalaya. Physiol. Mol. Biol. Plants 2014, 20, 399-403. [CrossRef]

92. Singh, B.; Borthakur, S.K. Phenology and Geographic Extension of Lycophyta and Fern Flora of Nokrek Biosphere Reserve of Eastern Himalaya. Proc. Natl. Acad. Sci. India Sect. B. Biol. Sci. 2015, 85, 291-301. [CrossRef]

93. Vashistha, R.K.; Rawat, N.; Chaturvedi, A.K.; Nautiyal, B.P.; Prasad, P.; Nautiyal, M.C. An Exploration on the Phenology of Different Growth Forms of an Alpine Expanse of North-West Himalaya, India. N. Y. Sci. J. 2009, 2, $29-40$.

94. Liu, J.; Liang, S.C.; Liu, F.H.; Wang, R.Q.; Dong, M. Invasive Alien Plant Species in China: Regional Distribution Patterns. Divers. Distrib. 2005, 11, 341-347. [CrossRef]

95. Walther, G.-R.; Roques, A.; Hulme, P.E.; Sykes, M.T.; Pyšek, P.; Kühn, I.; Zobel, M.; Bacher, S.; Botta-Dukát, Z.; Bugmann, H.; et al. Alien Species in a Warmer World: Risks and Opportunities. Trends Ecol. Evol. 2009, 24, 686-693. [CrossRef] [PubMed] 
96. LaFace, V.L.A.; Musarella, C.M.; Ortiz, A.C.; Canas, R.Q.; Cannavò, S.; Spampinato, G. Three New Alien Taxa for Europe and a Chorological Update on the Alien Vascular Flora of Calabria (Southern Italy). Plants 2020, 9, 1181. [CrossRef]

97. Reddy, C.S. Catalogue of Invasive Alien Flora of India. Life Sci. J. 2008, 5, 84-89.

98. Wu, S.H.; Sun, H.T.; Teng, Y.C.; Rejmánek, M.; Chaw, S.M.; Yang, T.Y.A.; Hsieh, C.F. Patterns of Plant Invasions in China: Taxonomic, Biogeographic, Climatic Approaches and Anthropogenic Effects. Biol. Invasions 2010, 12, 2179-2206. [CrossRef]

99. Lambdon, P.W.; Pyšek, P.; Basnou, C.; Hejda, M.; Arianoutsou, M.; Essl, F.; Jarošík, V.; Pergl, J.; Winter, M.; Anastasiu, P.; et al. Alien Flora of Europe: Species Diversity, Temporal Trends, Geographical Patterns and Research Needs. Preslia 2008, 80, 101-149.

100. Khuroo, A.A.; Weber, E.; Malik, A.H.; Dar, G.H.; Reshi, Z.A. Taxonomic and Biogeographic Patterns in the Native and Alien Woody Flora of Kashmir Himalaya, India. Nord. J. Bot. 2010, 28, 685-696. [CrossRef]

101. Randall, R.P. The Introduced Flora of Australia and Its Weed Status; CRC Press: Adelaide, Australia, 2007.

102. Diez, J.M.; D'Antonio, C.M.; Dukes, J.S.; Grosholz, E.D.; Olden, J.D.; Sorte, C.J.; Blumenthal, D.M.; Bradley, B.A.; Early, R.; Ibáñez, I.; et al. Will Extreme Climatic Events Facilitate Biological Invasions? Front. Ecol. Environ. 2012, 10, 249-257. [CrossRef]

103. Kohli, R.K.; Dogra, K.S.; Batish, D.R.; Singh, H.P. Impact of Invasive Plants on the Structure and Composition of Natural Vegetation of Northwestern Indian Himalayas1. Weed Technol. 2004, 18, 1296-1300. [CrossRef]

104. Khuroo, A.A.; Reshi, Z.A.; Malik, A.H.; Weber, E.; Rashid, I.; Dar, G.H. Alien Flora of India: Taxonomic Composition, Invasion Status and Biogeographic Affiliations. Biol. Invasions 2011, 14, 99-113. [CrossRef]

105. The IUCN Red List of Threatened Species, Version 2019-1. Available online: https:/ / www.iucnredlist.org (accessed on 12 August 2020).

106. Bijalwan, R.; Vats, M.; Joshi, S.P. Plant Phenological Response to Microclimatic Variations in an Alpine Zone of Garhwal Himalaya. J. Appl. Nat. Sci. 2013, 5, 47-52. [CrossRef]

107. Lanker, U.; Malik, A.R.; Gupta, N.K.; Butola, J.S. Natural Regeneration Status of the Endangered Medicinal Plant, Taxus baccata Hook.f. syn. T. wallichiana, in Northwest Himalaya. Int. J. Biodivers. Sci. Ecosyst. Serv. Manag. 2010, 6, 20-27. [CrossRef]

108. Paul, A.; Bharali, S.; Khan, M.L.; Tripathi, O.P. Anthropogenic Disturbances Lead to Risk of Extinction of Taxus wallichiana Zuccarini, an Endangered Medicinal Tree in Arunachal Himalaya. Nat. Areas J. 2013, 33, 447-454. [CrossRef] 